NUREG/CR-3055

PNL-4346

\title{
Review and Evaluation of Paleohydrologic Methodologies
}

Prepared by M. G. Foley, D. A. Zimmerman, J. M. Doesburg,

P. D. Thorne

Pacific Northwest Laboratory

Operated by

Battelle Memorial Institute

Prepared for

U.S. Nuclear Regulatory

Commission 


\section{NOTICE}

This report was prepared as an account of work sponsored by an agency of the United States Government. Neither the United States Government nor any agency thereof, or any of their employees, makes any warranty, expressed or implied, or assumes any legal liability of re. sponsibility for any third party's use, or the results of such use, of any information, apparatus, product or process disclosed in this report, or represents that its use by such third party would not infringe privately owned rights.

\section{Availability of Reference Materials Cited in NRC Publications}

Most documents cited in NRC publications will be available from one of the following sources:

1. The NRC Public Document Room, 1717 H Street, N.W. Washington, DC 20555

2. The NRC/GPO Sales Program, U.S. Nuclear Regulatory Commission, Washington, DC 20555

3. The National Technical Information Service, Springfield, VA 22161

Although the listing that follows represents the majority of documents cited in NRC publications, it is not intended to be exhaustive.

Referenced documents available for inspection and copying for a fee from the NRC Public Document Room include NRC correspondence and iriternal NRC memoranda; NRC Office of Inspection and Enforcement bulletins, circulars, information notices, inspection and investigation notices; Licensee Event Reports; vendor reports and correspondence; Cornmission papers; and applicant and licensee documents and correspondence.

The following documents in the NUREG series are available for purchase from the NRC/GPO Sales Program: formal NRC staff and contractor reports, NRC-sponsored conference proceedings, and NRC booklets and brochures. Also available are Regulatory Guides, NRC regulations in the Code of Federal Regulations, and Nuclear Regulatory Commission /ssuances.

Documents available from the National Technical Information Service include NUREG series reports and technical reports prepared by other federal agencies and reports prepared by the Atomic Energy Commission, forerunner agency to the Nuclear Regulatory Commission.

Documents available from public and special technical libraries include all open literature items, such as books, journal and periodical articles, and transactions. Federal Register notices, federal and state legisiation, and congressional reports can usually be obtained from these libraries.

Documents such as theses, dissertations, foreign reports and translations, and non-NRC conference proceedings are available for purchase from the organization sponsoring the publication cited.

Single copies of NRC draft reports are available free upon written request to the Division of Technical information and Document Controi, U.S. Nuclear Regulatory Commission, Washington, DC 20555.

Copies of industry codes and standards used in a substantive manner in the NRC regulatory process are maintained at the NAC Library, 7920 Norfolk Avenue, Bethesda, Maryland, and are available there for reference use by the public. Codes and standards are usually copyrighted and may be purchased from the originating organization or, if they are American National Standards, from the American National Standards Institute, 1430 Broadway, New York, NY 10018. 
NUREG/CR-3055

PNL-4346

\section{Review and Evaluation of Paleohydrologic Methodologies}

Manuscript Completed: September 1982

Date Published: December 1982

Prepared by

M. G. Foley, D. A. Zimmerman, J. M. Doesburg,

P. D. Thorne

Pecific Northwest Laboratory

Richland, WA 99352

\section{Prepared for}

Division of Waste Management

Office of Nuclear Material Safety and Safeguards

U.S. Nuclear Regulatory Commission

Washington, D.C. 20555

NRC FIN B2220 


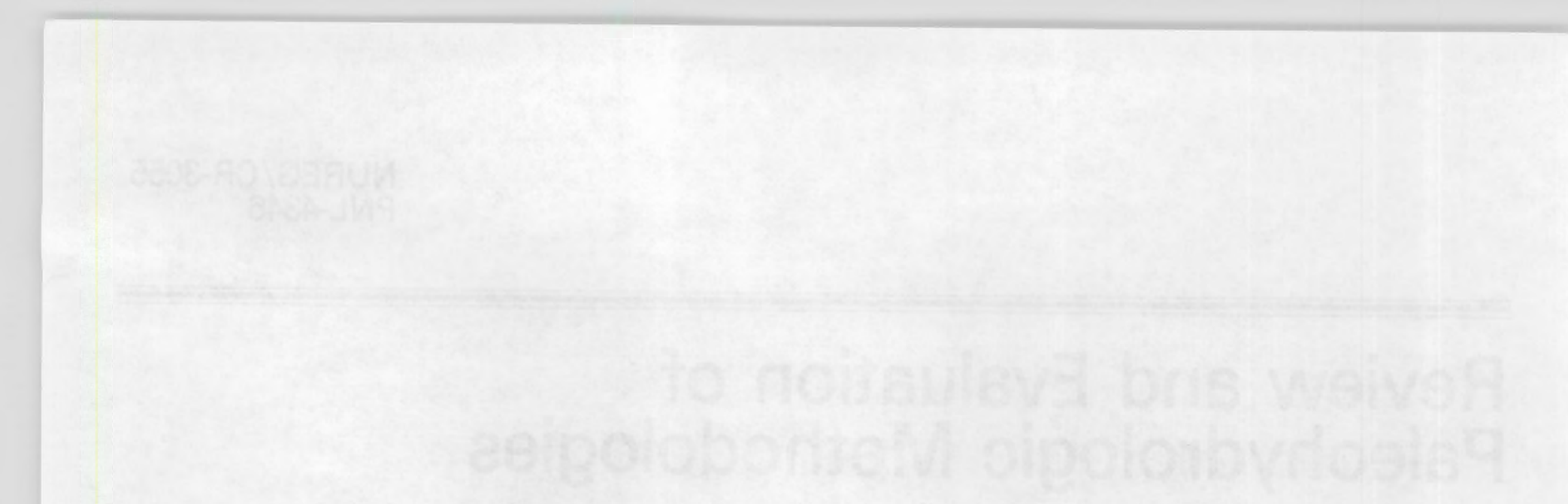




\section{SUMMARY}

Pacific Northwest Laboratory conducted a literature review to identify methodologies that could be used to interpret paleohydrologic environments. Paleohydrology is the study of past hydrologic systems or of the past behavior of an existing hydrologic system. The purpose of the review was to evaluate how well these methodologies could be applied to the siting of low-level radioactive waste facilities.

The computer literature search queried five bibliographical data bases containing over five million citations of technical journals, books, conference papers, and reports. Two data-base searches (United States Geological Survey-USGS) and a manual search were also conducted. As many of the identified publications as possible were collected, read, and analyzed to develop the lists of methodologies for synoptic, surface-water, and ground-water studies. The methodologies were examined for data requirements and sensitivity limits.

Paleohydrologic interpretations are uncertain because of the effects of time on hydrologic and geologic systems and because of the complexity of fluvial systems. Paleoflow determinations appear in many cases to be order-of-magnitude estimates. However, the methodologies identified in this report mitigate this uncertainty when used collectively as well as independently. That is, the data from individual methodologies can be compared or combined to corroborate hydrologic predictions. In this manner, paleohydrologic methodologies are viable tools to assist in evaluating the likely future hydrology of low-level radioactive waste sites. 


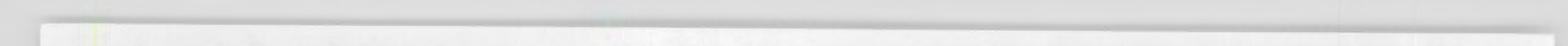




\section{CONTENTS}

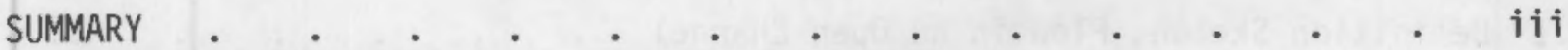

1.D INTRODUCTION

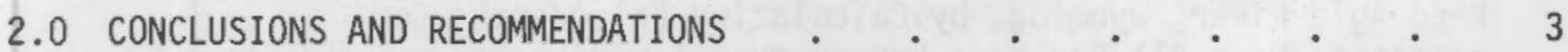

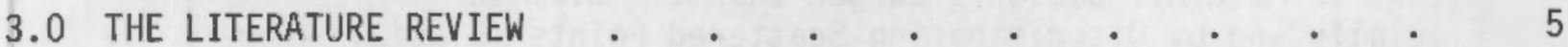

THE COMPUTER SEARCH . $. \quad . \quad . \quad . \quad . \quad . \quad . \quad . \quad . \quad 5$

THE MANUAL SEARCH

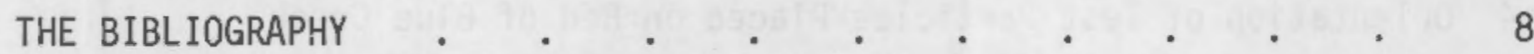

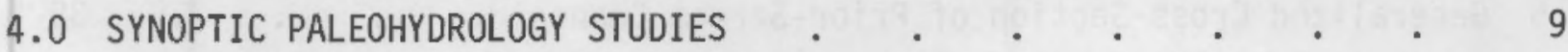

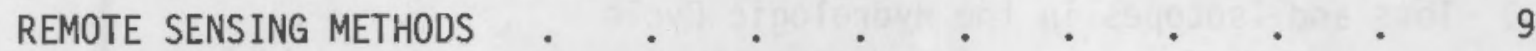

QUANTITATIVE RELATIONS (HYDRUALIC GEOMETRY) . $\quad . \quad . \quad . \quad 10$

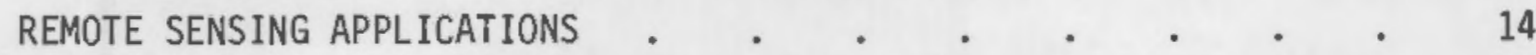

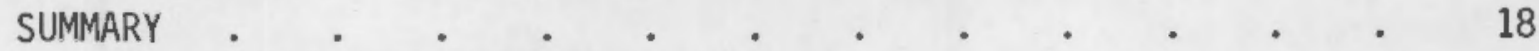

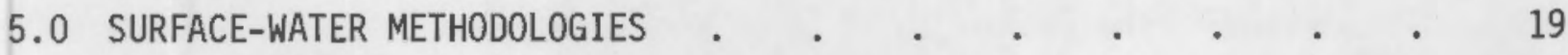

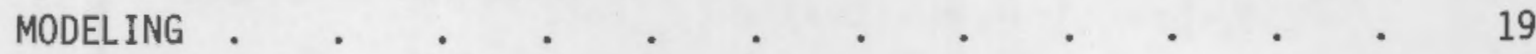

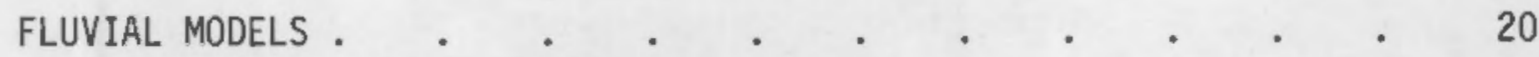

QUANTIFYING INDIVIDUAL PARAMETERS $\quad . \quad . \quad . \quad$. $\quad . \quad 24$

COMBINED METHODOLOGIES . . . . . . . . . . . . 40

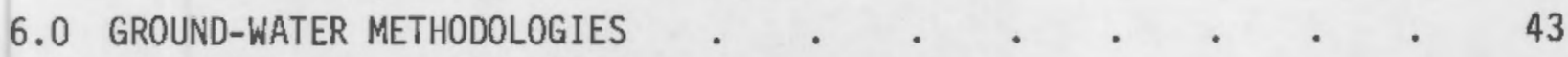

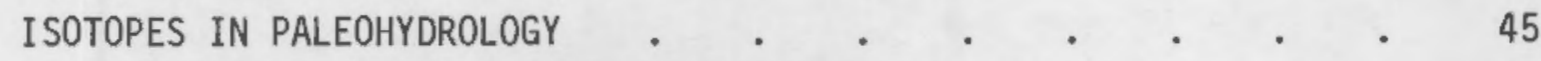

GEOCHEMICAL TECHNIQUES IN PALEOHYDROLOGY $\quad . \quad$. $\quad . \quad$. 50

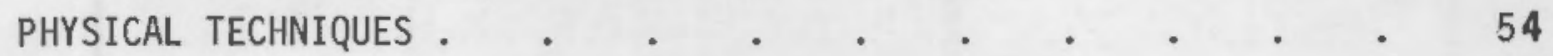

REFERENCES . . . . . . . . . . . . . . . . 57

BIBLIOGRAPHY . . . . . . . . . . . . . . . 63 


\section{FIGURES}

5.1 Definition Sketch, Flow in an Open Channel . . . . . 22

5.2 Estimation of Paleowater Surface in the Middle Fork of the Popo Agie River, Wyoming, by Calculating Paleodepths Competent to Move All Boulders Larger than $1 \mathrm{~m}$ Diameter Fluvially and by Discriminating Scattered Points (Glacial Erratics?) from Grouped Ones (Fluvial?). . . . . 32

5.3 Types of Bedforms in Quasi-Equilibrium Unidirectional Flows . $\quad 34$

5.4 Orientation of Test Particles Placed on Bed of Blue Creek . . 36

5.5 Generalized Cross-Section of Prior-Stream Channel . . . . 39

6.1 Ions and Isotopes in the Hydrologic Cycle . . . . . 46 


\subsection{INTRODUCTION}

Pacific Northwest Laboratory $(\mathrm{PNL})^{(\mathrm{a})}$ contracted with the Nuclear Regulatory Commission (NRC) to identify methodologies that can interpret paleohydrologic environments. Paleohydrology is the study of past hydrologic systems or of past behavior of an existing hydrologic system. Paleohydrologic studies are necessarily indirect because the original water in the system is gone. This report summarizes quantitative and semiquantitative techniques for estimating the past behavior of a hydrologic system. This past behavior could indicate a system's future behavior. Such an extrapolation may be as quantitative as an indirect discharge estimate of present floods, or as qualitative as an order-of-magnitude or bounding estimate of discharge, or of potentiometric surface elevation.

The objective of this study was to review the available literature and ongoing studies on paleohydrology and to evaluate the applicability and limitations of the various methodologies for siting near-surface disposal facilities for low-level radioactive waste. The methods reviewed were to apply to sites in the humid eastern United States as well as to arid sites in the western United States. Near-surface disposal facilities at these sites must (ref., 10CFR61) be located in the unsaturated zone, and must remain above the groundwater table for the period of isolation. Ground-water paleohydrologic methodologies can be used to gain confidence that water table fluctuations will not affect the facility. Surface water studies were also included in this report to provide methodologies for estimating the long-term behavior (500 years or more) of ungaged first-order streams near proposed sites.

This report bases the surface-water paleohydrologic techniques on the hydraulics of open-channel flow in alluvial channels; it bases the ground-water techniques on Darcian flow through porous media as well as on stable and unstable isotope geochemistry of meteoric waters and transported materials. These methodologies apply to Quaternary flows of a million years ago and to flows that deposited sandstones now billions of years old, just as they apply to

(a) Operated by Battelle Memorial Institute 
yesterday's hydrology. The techniques are 1 imited by the preservation of features related to flow parameters. Fewer data are available for older flows of interest, and features are usually preserved longer in arid climates than in humid ones. However, the fundamental paleohydrologic techniques are the same in all cases.

Although hydrology and climate are intimately related, paleoclimatology has not been included explicitly in this project. Such an undertaking would have been far beyond the scope of this study, and would have increased the amount of bibliographic material many times. However, paleoclimatic techniques cannot always be separated from paleohydrologic techniques, and have been included here when they are intimately connected to hydrologic methods.

This report begins with an explanation of the literature review itself. Methodologies for synoptic, surface-water, and ground-water paleohydrological studies are summarized and a synthesis of the individual techniques is discussed. A bibliography, including foreign language references, follows. 


\subsection{CONCLUSIONS AND RECOMMENDATIONS}

Three general areas of paleohydrologic research provide useful techniques for estimating past hydrologic conditions relevant to the siting of low-level radioactive waste repositories. They are: 1) synoptic paleohydrology studies, 2) surface-water methodologies, and 3) ground-water methodologies. The techniques identified in each of these areas rely on empirical models or on quasideterministic models that combine known physical principles with empirical relations for estimating the values of hydrologic parameters of flows in past, present, or future hydrologic systems.

Synoptic paleohydrology studies use information that characterizes hydrologic conditions affecting a large geographical area. Remote sensing provides information on the color and albedo differences of the earth's surface; analysis of the imagery enables one to make inferences on the vegetation patterns, the underlying geologic structure, and the characteristics of surface paleochannels. Channel parameters amenable to analysis through remote sensing methods include channel dimensions, shape, pattern and sinuosity, gradient, and type of sediment being transported. Calculations of discharge, velocity, and sediment type can be made using empirical equations. Through these calculations, past hydrologic behavior can be inferred where adequate channel deposits are preserved, and thus future behavior relevant to the siting of near-surface disposal facilities can be extrapolated.

Surface-water paleohydrologic studies depend on the flexible, ad hoc application of open-channel flow hydrology to the estimation of paleoflows, and suffer from increasing degrees of uncertainty with decreasing knowledge of the paleoflow channel geometry and water surface profile. Estimates of paleoflows in existing channels with reliable high-water indicators and stable cross-sections have the least uncertainty, perhaps as little as a few percent in the most favorable cases. If high-water indicators are unreliable or missing, sediment initiation-of-motion criteria can be used in some cases to estimate flow depth, but such indicators may have uncertainties of more than 100 percent. Uncertainities of 100 percent or greater are also introduced when the paleochannel no longer exists, and its geometry must be estimated from sedimentological data. More sophisticated, computerized techniques are available for estimating flows 
in existing channels; however the sparse data available for most surface-water paleohydrologic studies seldom warrant the use of these methods. The use of several independent approaches can sometimes (depending again on the availability of data) indicate the range of uncertainty of the results.

Ground-water paleohydrologic techniques identified in this report fall into three groups. Techniques related to unstable isotopes use transport phenomena and decay times to determine residence time and travel time for ground water. Geochemical techniques can be used to determine the recharge area or the types of materials that a ground water has flowed through. Physical techniques demonstrate visible changes in materials that result from past action of ground water, and thereby indicate where the water table has been in the past. Most paleohydrologic studies use a combination of techniques to determine past conditions.

Almost all of the paleohydrological techniques discussed in this report are the result of ad hoc, informed application of technology from a variety of scientific disciplines to a particular problem often having an unusually abundant (relatively) data source. Thus, in its present state of development, paleohydrology is as much an art as a science and should be pursued by experts using multiple, independent approaches. For this reason, the approach we have taken in presenting paleohydrologic methodologies is to discuss what has been done in the context of as systematic a review of the relevant scientific principles as is possible or relevant. The result cannot be used as a handbook for paleohydrologic studies, but enough references have been included to guide the reader to more detailed approaches to specific problems. 


\subsection{THE LITERATURE REVIEW}

The literature search began with a search of several computer data bases for references indexed by the key word "paleohydrology." Articles of apparent relevance to this review were obtained either from the PNL technical library or through interlibrary loans. Review of these articles suggested new descriptors or key words for use in a second computer search. At the same time, cited references in each article were used to explore for references not contained in the computer data bases. Also, a manual search of the Hanford Technical Library was performed to find additional references. Again, cited references from articles located in this search were checked to obtain new references.

As the volume of references and articles increased, identifying references already cited became difficult. To help keep track of the growing reference list, a computer data base, with a capability similar to the commercial data bases mentioned above, was developed to manage the bibliographic data. This facilitated organization and retrieval of specific information, prevented duplication of research, and eliminated many manual processes. The result was as thorough a search of the literature as could be devised, with an accurate and comprehensive accounting of every aspect of the search, and a system for managing the information that proved invaluable to the literature review itself.

\section{THE COMPUTER SEARCH}

Five bibliographical data bases containing over five million citations of technical journals, books, conference papers, reports, and theses of both national and international origin were searched:

- GEOREF

(1961 to present) covers all aspects of geology, geochemistry, geophysics, mineralogy, paleontology, petrology, and seismology.

- GEOARCHIVE (1969 to present) covers the same fields as GEOREF.

- WRA

(Water Resource Abstracts) (1968 to present) covers all water-related aspects of the physical, life, and social sciences. Input to WRA is from selected institutions with active water research programs. 
- DOE ENERGY

(1974 to present) covers primarily energy topics--e.g., nuclear, geothermal, fossil, and tidal.

- SCISEARCH

(1974 to 1977) covers technical and scientific literature of pure and applied science. It contains all the records published in the Science Citation Index.

In addition, two USGS computer data bases were searched for this task. In Reston, Virginia, a data base containing all the publications of the USGS was searched and the results were forwarded to PNL. The USGS office in Denver, Colorado, performed a computer search on a special data base containing articles dealing with the geology, geophysics, and hydrology in the vicinity of nuclear testing areas. Many records listed in that file are "for official use only," and are available only to government agencies and their prime contractors. Hence, these records are not listed in any of the publicly accessible data bases mentioned above.

A wealth of additional pertinent information could be obtained by examining the literature on paleoclimatology, which directly influences the paleohydrology. However, as discussed in the Introduction, this is beyond the scope of this task, and would have significantly increased the amount of information to be processed, perhaps by an order of magnitude. By applying restrictions, such as having the key word appear only in the title or only in the abstract, or by requiring only English language reports, the number of references actually extracted from the data bases amounted to less than 500 . The foreign language articles could not be effectively reviewed in the time allotted, although the foreign language references are included in the bibliography. In all, over 400 references were extracted from the data bases; the articles obtained from this list served as a starting point for the literature review.

THE MANUAL SEARCH

To initiate this search, the printed references from the computer data bases were examined and appropriate articles were obtained. As each article was acquired, its bibliography was checked and new articles were sought. At the same time, three other searches were underway: 
1. The card catalogue was searched for books or other publications containing relevant information. Subjects searched included paleo, ancient, hydrology, and hydraulic measurement.

2. A list of in-house journals was examined and those journals that appeared to have a reasonably good chance of containing relevant articles were selected. If a journal from this selection contained a yearly subject index, it was examined. 0therwise, when time permitted, the table of contents of the other journals were inspected. The list of journals with end-of-year subject indexes included: Water Resources Bulletin (19741980); Groundwater (1963-1969); American Journal of Science (1972-1980); Technology Review (1972-1975); and Remote Sensing and the Environment (1970-1980).

3. As the SCISEARCH (Science Citation Index) computer data base contained information only for the years 1973-1977, the periods 1961-1972 and 19781981 remained to be reviewed. Initially, the permuterm (subject) index was searched. Then, after accumulating several hundred references in the "paleohydrologic reference data base," several prominent authors in the field were identified. At this point, the source (author) index, which lists all the articles published by the author in each year, was searched.

From the list of 400-plus references obtained through the computer searches and the additional references obtained through the manual search, over 300 references were entered into our computerized bibliographic data base. References that appeared to contain significant relevant information were ordered through the Hanford Technical Library. As articles were received, they were reviewed to determine the general nature of their content (i.e., whether the techniques discussed pertained to surface-water techniques, ground-water techniques, or synoptic methods). The area of applicability for each reference reviewed was indicated in the bibliographic data base. This allowed all the references pertaining to a particular area of applicability to be extracted from the data base, assisting the literature review process. 


\section{THE BIBLIOGRAPHY}

Many of the references in the data base were not ordered or were written in a foreign language, precluding a complete listing of the references by subject category (area of applicability). In addition, many articles contained information relevant to more than one area of applicability; hence, the bibliography is listed in alphabetical order by author.

The manual search for references in the Hanford library was complimented by searches in the University of Missouri, Columbia library and by searches in the University of Washington library. The Quaternary Research Library (University of Washington) was specifically targeted for paleohydrologic studies. The references collected were added to the bibliography and included where appropriate in the text of this report. 


\subsection{SYNOPTIC PALEOHYDROLOGY STUDIES}

Synoptic paleohydrology studies, as used here, are empirical methodologies that yield data characterizing the hydrological conditions affecting a relatively large geographical area, or that depend on data averaged over a large area. These studies depend in part on remote sensing methods that provide improved perspective of the earth's surface. Other inputs to synoptic paleohydrologic studies come from areal field data on palynology, dendrochronology, and paleontology. Remote sensing of drainage basins provides qualitative information on past changes in hydrology (primarily surface waters) or imminent future changes. Remote sensing data combined with empirical observational data can provide semiquantitative estimates of the hydraulic properties of present or abandoned stream channels. Detailed chronological studies of areal vegetation distributions and growth rates can help relate effective precipitation to runoff, thereby providing an estimate of the recharge that was available for ground water in the past.

\section{REMOTE SENSING METHODS}

Remote sensing methodologies use reflected and emitted electromagnetic energy for producing spectral images of the earth's surface. Every object or material has unique properties that influence the reflection, absorption, and emission of different portions of the electromagnetic spectrum. The signature produced by these reflections and emissions can be correlated with the type of material. The most important advantage remote sensing offers is the synoptic view it provides of surficial patterns, shapes, and of differences in surface color and albedo (reflectivity).

The analysis of aerial and satellite imagery facilitates the recognition and mapping of subtle or poorly expressed hydrologic features that are difficult to identify by ground-based methods. The direct appearance on aerial or orbital photographs, or the specular reflection on other imagery, of vegetation and drainage patterns provides quantifiable information on the ground-water system recharge and discharge distributions (with appropriate ground truth). Vegetation patterns and type help identify shallow water-bearing zones. Seasonal 
variations in climate and foliage will significantly influence the photographic tones and vegetation patterns shown on the imagery. Also, the synoptic view of the surface aids in the characterization of landforms, the discrimination of mappable geologic units, and the delination of otherwise obscure lineaments, especially when aided by sophisticated computerized image analysis. More specific to this study, the topographic and geometric features depicted on the imagery provide data on the characteristics of surface paleochannels from which some hydraulic calculations can be made.

\section{QUANTITATIVE RELATIONS (HYDRAULIC GEOMETRY)}

Many empirical equations relating river discharge, sediment load, and channel shape and gradient use some areal parameters with values that can be determined more accurately from aerial photographs. For example, studies have shown that channel meander dimensions are related to the volume of water discharged through the channel, that channel dimensions and shape are related to the type of sediment load, and that channel gradient depends on past hydrologic conditions.

Dury (1965) found a relation between meander wavelength ( $L$ in feet) and bankfull discharge $\left(Q_{b}\right.$ in $\left.c f s\right)$ according to:

$$
L=30 Q_{b}^{0.5}
$$

The scatter in the data used to develop this relation ranges over an order of magnitude and may reflect the influence of other variables. Schumm (1968) hypothesized that the type of sediment load moved through the channel has a significant influence on the meander wavelength. When the sediment load (expressed as the percentage of silt-clay exposed in the bed and banks of the channel, and defined as:

$$
M=\frac{\left(M_{b}+W\right)+\left(M_{b} \cdot 2 D\right)}{W+2 D} \text {, }
$$


where

$$
\begin{aligned}
& M_{c}=\text { percentage of silt-clay taken from the floor of the channel, } \\
& M_{b}=\text { percentage of silt-clay in the banks of the channel, } \\
& D=\text { maximum bankfull depth, and } \\
& W=\text { bankfull width of the channel) }
\end{aligned}
$$

is included in the regression analysis (Schumm 1968), an improved relation is obtained for both mean annual discharge (Qm in cfs) and mean annual flood (Qma in cfs) as:

$$
\begin{aligned}
& L=1890 \cdot \frac{Q_{m}^{0.34}}{M^{0.74}} \text {, and } \\
& L=234 \cdot \frac{Q_{m a}^{0.48}}{M^{0.74}} .
\end{aligned}
$$

An estimate of the type of sediment load (M) can be inferred from the channel morphology and mode of sediment transport (Schumm 1977, pp. 155-156). Additionally, Schumm (1977) developed relations that demonstrated that both type of sediment load $(M)$ and discharge $(Q)$ have a determining influence on channel morphology according to:

$$
\begin{gathered}
W=37 \cdot \frac{Q_{m}^{0.38}}{M^{0.74}}, \\
W=2.3 \frac{Q_{m a}^{0.58}}{M^{0.37}}, \\
D=0.59 M^{0.34} \cdot Q_{m}^{0.29},
\end{gathered}
$$


and

$$
D=0.09 \mathrm{M}^{0.38} \mathrm{Q}_{\mathrm{ma}}^{0.42}
$$

Bray (1973) formulated a relation between these same stream parameters and the discharge for a flood with a two-year recurrence interval $\left(Q_{2}\right.$ in cfs) for gravel-fed streams in Alberta, Canada, as:

$$
\begin{aligned}
& W=2.38 Q_{2}^{0.527} \text {, and } \\
& D=0.266 Q_{2}^{0.333} .
\end{aligned}
$$

The channel depth and width in the above equations are the bankfull depth and width. Channel width can be determined from photographic tones, and vegetation and sediment patterns. The depth of dry channels can be determined using photogrammetric techniques.

The shape of stable alluvial stream channels, as expressed by the widthto-depth ratio (F), has been shown (Schumm 1977) to primarily depend on the silt-clay content (M) of the perimeter according to:

$$
F=115 \mathrm{M}^{-1.08}
$$

Schumm combined the data on channel shape, silt-clay content, and discharge to derive the following equations:

$$
F=56 \frac{Q_{m}^{0.10}}{M^{0.74}}
$$

and

$$
F=21 \frac{Q_{m}^{0.18}}{M^{0.74}}
$$


River gradient depends primarily on the slope of the valley that was established by the river during times of possibly very different $\mathrm{climatic}$ and hydrologic conditions, and to a lesser degree on the type of sediment load and discharge moving through the modern channel (Schumm 1968). Schumm found that for stable alluvial rivers the channel gradient (SC) could be related to the valley gradient (Sv), type of sediment load $(M)$, and discharge $(Q)$, according to:

$$
S_{c}=1.3 \frac{S_{v}^{0.94}}{M^{0.23} Q_{m}{ }^{0.02}}
$$

Bray (1973) found that for rivers of Alberta, the channel gradient was related to the two-year recurrence interval flood and the median grain size $\left(d_{50}\right.$ in $\left.\mathrm{mm}\right)$ according to:

$$
S_{C}=0.965 Q_{2}^{-0.334} \cdot d_{50}{ }^{0.58} .
$$

Most of the above equations relate channel parameters to discharge; relations among channel parameters exclusive of discharge have also been established. Leopold and Wolman (1960) related meander wavelength (L) to channel width $(W)$ and radius of curvature $(R)$ according to:

$$
L=10.9 \cdot W^{1.01} \text {, }
$$

and

$$
L=4.7 \cdot R^{0.98} \text {. }
$$

Hack (1957) determined for streams in Maryland and Virginia that channel gradient is related to drainage basin area ( $A$ in square feet) and median grain size as: 


$$
S_{C}=18 \frac{d_{50}}{A} .
$$

Discharge does not significantly influence the relation between sinuosity, the ratio of channel length to valley length, and the type of sediment load, because the sinuosity of a small stream can be nearly the same as that of a large river if the two are transporting similar types of sediment (Schumm 1968). Schumm found that for rivers of the Great Plains the sinuosity (P) is related to the channel's width-to-depth ratio (F) (Schumm 1963) and to the type of sediment load (M) (Schumm 1968) according to:

$$
P=3.5 \cdot F^{0.27} \text {, }
$$

and

$$
P=0.94 M^{0.25} .
$$

The foregoing empirical formulae coupled with data from aerial photographs can be used to make hydraulic estimates in ungaged rivers or paleochannels. However, because of the complexity of the fluvial system and the variability in the data used to derive these formulas, discharge estimates based on these relations could at best give only an indication of the relative magnitude of the event.

\section{REMOTE SENSING APPLICATIONS}

Synoptic studies rely in large part on a combination of remote sensing and empirical modeling. For use in quantitative paleohydrology, uncertainties of synoptic studies can be order-of-magnitude unless a substantial data base is available, or unless specific ground-truth studies have been conducted. For example, a gravel pit centered on a paleochannel of the Murrumbidgee River, Australia, revealed deposits of cross-bedded sand that indicated the channel width was much larger than its surface expression as measured from aerial photographs (Schumm 1968). 
A study of the Murrumbidgee River and its associated paleochannels (Schumm 1968) provided data for making paleoflow estimates. Methods of investigation included obtaining data from records at gaging stations, collecting and analyzing sediment samples, and taking measurements from aerial photographs. Radiocarbon dates of soil samples of 36,000 years ( $P$ els 1964) and 28,000 years (Langford-Smith 1959) indicated a Pleistocene age for the paleochannels. Traces of paleochannels and the extent of the ancient flood plain were evidenced on the aerial photographs by meander scars and oxbow lakes. The width of the flood plains and the dimensions of the meander scars were much larger than the same dimensions of the modern Murrumbidgee River, indicating that past discharges were considerably larger than at present.

Schumm made crude estimates of water volume and sediments passing through the paleochannels. The Manning equation (refer to Section 5.0) was applied under the assumption that channel roughness and gradient were the same as the modern Murrumbidgee River. Bankfull discharge was calculated to be about five times greater than that in the Murrumbidgee River. Dury's equation [Equation (4.1)] relating bankfull discharge to meander wavelengths was applied using measurements taken from aerial photographs; discharge estimates were in agreement with estimates using Manning's equation. The sinuosity from the modern Murrumbidgee River and its paleochannels was plotted against the channel's width to depth ratio (F) and silt-clay content (M); the data conformed to the relations [Equations (4.19) and (4.20)] described earlier. The width-to-depth ratio versus silt-clay content relation also conformed to Schumm's relation, Equation (4.11).

Schumm concluded that the differences in the width-to-depth ratio and the channel sinuosity of the modern Murrumbidgee River and its paleochannels could be explained by a change in the sediment type, but that the change in channel dimensions (meander wavelength, channel width and depth) necessarily resulted from a change in discharge. Therefore, a major change in the hydrologic regimen of the system had occurred.

Holtz and Baker (1979) distinguished three major river types based on sinuosity and other parameters and used empirical formula to estimate their hydrologic properties from information obtained from photographs taken during 
the Apollo-Soyuz Test Project (ASTP) in 1975. The rivers were distinguishable by their size and morphology and were classified according to the environments of their drainage basins. Channel width, meander wavelength, and sinuosity measurements were taken from the photographs and used to calculate the widthto-depth ratio (F) and silt-clay content (M) according to Schumm's relations [Equations (4.19) and (4.20)]. The values calculated were used to indicate the general character of the rivers, not to make quantitative predictions. One reason for this caution was that these rivers are anastomosing in form in a tropical environment, unlike the single channel reaches in the semi-arid Great Plains where the empirical relations were derived. The sinuosity of the Jurura River, Brazil, was quantified from the ASTP photographs for the past and present. Abandoned channels and meander scars were used for making paleosinuosity estimates. Meander wavelength measurements were used to make discharge estimates using Dury's relation [Equation (4.1)]. However, a lack of field data for ground truth prevented verification. Of these estimates, Holtz and Baker found that Schumm's formulae [Equations (4.19) and (4.20)] were not always consistent with the photographic evidence because of the complex nature of bank resistance of tropical streams and because of a general lack of precise understanding of the behavior of tropical rivers.

Thomas and Benson (1970) demonstrated that streamflow characteristics can be related to basin characteristics through multiple regression techniques that extrapolate information at gaged sites to ungaged sites. Allord and Scarpace (1979) studied two basins in Wisconsin to see if LANDSAT imagery could be used to improve the equations developed to predict streamflow characteristics at ungaged sites. The LANDSAT images were analysed to provide land cover information. Land-use categories were classified as forest, grassland, water, wetland, mixed vegetation type, bare soil, and cropland. The spectral signatures of each class were determined from areas known to be representative of each land-use category. These signatures were used to classify the LANOSAT images into land-use categories and the data were used to develop relations for low flows and flood flows by the USGS method (Thomas and Benson 1970). Four of the nine basin characteristics determined from satellite imagery were significant variables in multiple regression techniques, whereas only 
1 of 12 variables determined from topographic maps was significant. Estimates of the 7-day low flow at 2- and 10-year recurrence intervals were improved 17 to $20 \%$. Similarly, flood frequency estimates for $10-, 50$ - and 100 -year recurrence intervals were improved 45 to $50 \%$.

The Mariner 9 (Baker 1981) and Viking missions returned photographic evidence of trough-like features on the Martian surface that are considered to be relict fluvial channels. The outflow channels display a variety of morphological features that also characterize the great Pleistocene flood channels that scoured through loess and basalt bedrock in the Channeled Scablands of eastern Washington (Baker 1971; Bretz 1969; Carr 1979).

A basic assumption of terrain analysis (Way 1978) is that landforms developing under similar conditions of age, weathering, climate, erosion, and relief will exhibit a characteristic set of visual and physical attributes, no matter where the landform is found. Also, recurrence of the landform implies a recurrence of the basic characteristics of the landform (i.e., soil and rock properties, topography, drainage pattern, ground-water conditions). On this premise, the features observed on the Martian surface are interpreted as having a fluvial origin.

Viking photographs of the Martian surface revealed a distinctive assemblage of channel landforms: anastomosing patterns, streamlined hills, inner channels with cataracts, pendant forms on the downcurrent side of flow obstacles, expanding and contracting reaches associated with flow constrictions, longitudinal grooves aligned parallel to fluid flow direction, and scour marks around obstacles. The only terrestial landscape that contains analogs to all the Martian outflow channel landforms is the Channeled Scablands of eastern Washington (Carr 1979). The common features include longitudinal grooves, teardrop-shaped (streaml ined) islands, inner channel cataracts, terraced margins, and angular floor depressions. The lack of tributaries and the resemblance to the Channeled Scablands has led investigators to believe that the Martian channels were formed by catastrophic floods.

Estimates of discharge in some of the channels were made by applying the Chezy-Manning formula (refer to Section 5.0). The estimates of peak discharge 
in two Martian valleys ranged from $7 \times 10^{6} \mathrm{~m}^{3} / \mathrm{sec}$ to $5 \times 10^{8} \mathrm{~m}^{3} / \mathrm{sec}$. Channel depths were estimated from shadow measurements or from evidence of flow around ejecta ramparts. Channel depth is only an indicator of maximum depth of water; hence, the estimates ranged over several orders of magnitude.

Carr (1979) proposed that the large channels were eroded by water released rapidly, under great pressure, from deeply buried aquifers. Carr's hypothes is suggested the following: The ancient porous near-surface rocks of the Martian surface acted as a sink for water in the planet's early history when climatic conditions were more temperate than at present. Subsequent global cooling sealed the ground water beneath a thick permafrost layer to form a system of confined aquifers. Episodic breakout from the confined aquifers under large artesian pressure formed the flood features. Carr estimated the discharge that could result under this hypothesis using the basic equation for ground-water flow in a confined aquifer (Deju 1971). Aquifer transmissivity was estimated by assuming a value representative of basaltic sequences on earth. Estimates of discharges for various aquifer thicknesses and chaos area (area where breakout was assumed to have occurred) ranged from $1 \times 10^{4} \mathrm{~m}^{3} / \mathrm{sec}$ to $6.1 \times 10^{6} \mathrm{~m}^{3} / \mathrm{sec}$.

\section{SUMMARY}

Synoptic paleohydrology studies use information that characterizes hydrologic conditions affecting a large geographical area. Remote sensing provides information on the color and albedo differences of the earth's surface; analysis of the imagery enables one to make inferences on the vegetation patterns, the underlying geologic structure, and the characteristics of surface paleochannels. Channel parameters amenable to analysis through remote sensing methods include channel dimensions, shape, pattern (sinuosity), gradient, and type of sediment load. Calculations of discharge, velocity, and sediment type can be made using empirical equations. Through these calculations past hydrologic behavior can be inferred, and thus, future behavior relevant to the siting of near-surface disposal facilities can be extrapolated. 


\subsection{SURFACE-WATER METHODOLOGIES}

Quantitative surface-water paleohydrology is analyzed by the same techniques used for analyzing the hydrology of existing streams. A method useful for determining the flow parameters of yesterday's flood in an ungaged stream is also applicable to the study of flows that occurred tens of thousands of years ago. The only difference is that the features that are the basis for determining flow parameters tend to become obliterated over time by slope development processes and continued fluvial erosion and deposition. These processes usually operate at faster rates in humid environments, resulting in an apparent bias toward arid environments in studies of older flows.

Methodologies useful for surface-water paleohydrology are based primarily on the hydraulics of flows in open, alluvial channels and on the sediment transport mechanics of open channels. Additional techniques, based on observational data, relate channel geometric parameters and have been discussed in Section 4.0 under the heading "hydraulic geometry." All methodologies are subject to uncertainty, the amount varying with the type of field data available and the complexity of the channel being studied. This section presents the physical basis of the hydraulics of flow and sediment transport in alluvial channels as a framework to discuss specific surface-water paleohydrologic methodologies, and discusses techniques for determining individual parameters and their relative uncertainties. These uncertainties can be reduced by the use of several, redundant approaches and by the use of combined methodologies that will be discussed at the end of this section.

\section{MODELING}

The study of flow in open, alluvial channels is extremely difficult in detail because the flows interact with the bed and banks to make a self-formed channel. Further, each channel is a historical record of past erosional and depositional events, and cannot be treated in detail by a generic physical model. Foley (1980a) discussed the analysis of such channels in terms of three classes of models, which are relevant to the entire field of paleohydrology: 
"a deterministic class, in which known physical principles and initial and boundary conditions allow accurate description of system behavior; a stochastic class, in which systems are assumed to have inherent randomness and cannot be described by deterministic methods; and a parametric class, in which empirical relations among system variables may give some ability to predict system behavior."

Purely deterministic models of systems such as alluvial channels require overwhelming quantities of data (literally, every grain of sand), and have yet to be formulated. Parametric models, based on observations of field and laboratory channels, are the basis of "hydraulic geometry" methodologies (discussed in Section 4.0). These too require an overwhelming amount of data to have a model that can be applied to a specific channel; however, approximate applications are possible if the channel being analyzed is similar to the one observed. Uncertainties increase dramatically with increasing difference between properties of the observed and analyzed channels.

Foley (1980a) suggested that "a middle ground may exist between deterministic and parametric modeling, in which data-input requirements are minimized but output accuracy is compromised by use of lumped parameters whose details are unknown, but whose variability about some 'mean' may be estimated." Foley further suggested that such "quasi-deterministic" models may have some predictive capabilities outside the envelope of observed data that are lacking in parametric models.

\section{FLUVIAL MODELS}

The basis for hydraulic and sedimentological studies of alluvial, open channels of use in paleohydrology is a collection of quasi-deterministic flow and sediment-transport equations that rely on several lumped, empirical parameters. These contribute both to the ability of the models to address real hydrologic problems, and to the uncertainties inherent in those applications. The equations of general interest are those relating channel geometric parameters to flow resistance and amount, as these establish an analytical relation 
between variables of interest and ones with values that cab be determined in the field. Other empirical and quasi-deterministic relations between channel sediment properties and flow or geometric parameters will be discussed in more detail later in this section.

\section{Shear Stress}

An open-channel flow that does not vary with time (steady) or position along the channel (uniform) is such that the frictional resistance exerted by the channel periphery is balanced by the gravitational acceleration of the flow along the channel. It can be shown (Blatt et a1. 1980) that this equilibrium requires that:

$$
\tau_{0}=\rho g \frac{A}{P} \frac{h}{L},
$$

where $\tau_{0}$ is the average shear stress on the bed and banks, $p$ is the density of the water, $A$ is the cross-sectional area of the flow (see Figure 5.1), $P$ is the wetted perimeter of the flow, and $h$ is the drop along a length $L$ of the channel. The ratio $\frac{A}{P}$ is usually referred to as $r$, the hydraulic radius. Channel slope $S=\frac{h}{\cos L}$ is approximately equal to $\frac{h}{L}$ for small channel inclinations, and the usual definition of $\tau_{0}$ for steady, uniform flow is:

$$
\tau_{0}=\rho g r S \text {. }
$$

Henderson (1966) has shown that, for nonuniform flow, $S$, must be replaced by the friction slope:

$$
S_{f}=\frac{d}{d x}\left(h+\frac{v^{2}}{2 g}\right) \text {, }
$$

where $x$ is the along-channel direction and $V$ is the mean flow velocity in a cross-section, defined in relation to the flow volumetric discharge, $Q$, as:

$$
V=\frac{Q}{A} .
$$




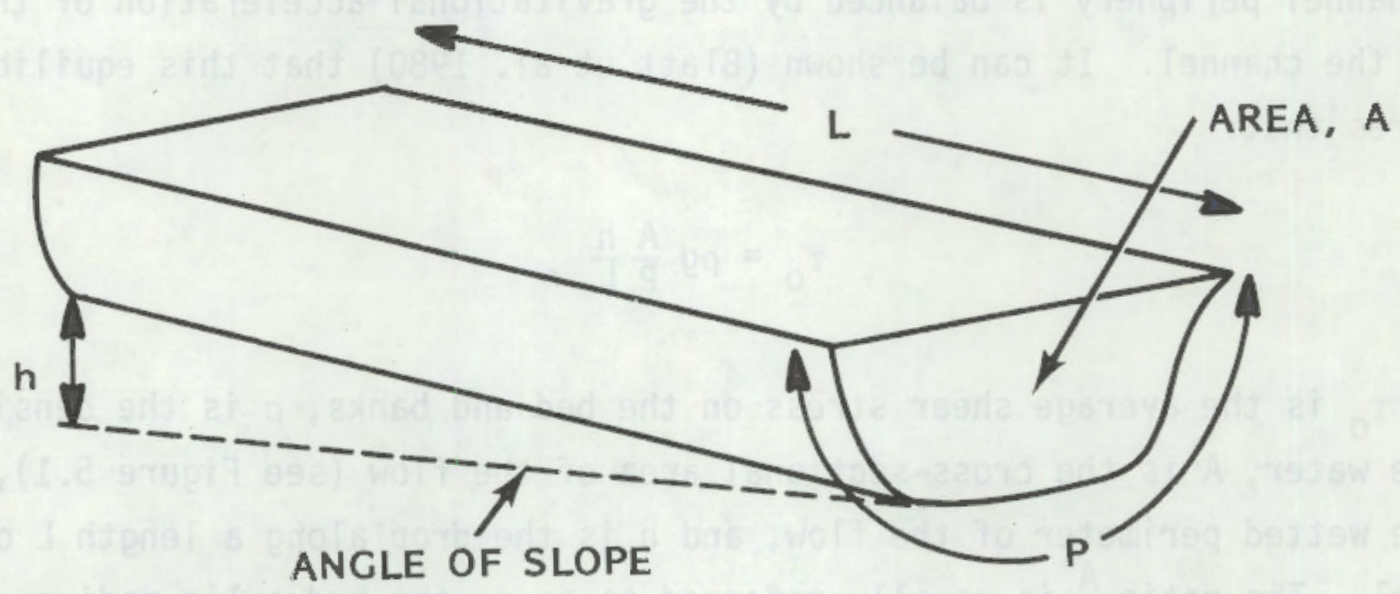

FIGURE 5.1. Definition Sketch, Flow in an Open Channel

The equilibrium-of-forces derivation of the equation for shear stress assumes that no nonfrictional energy losses occur in the flow. Flow separations around obstacles or at sudden expansions in the channel periphery, free overfalls, hydraulic jumps, and other energy losses will invalidate the above shear-stress relation, and must be avoided in reaches to be included in paleohydraulic analyses. Some special types of nonfrictional energy losses related to expanding channel reaches can be approximated, as will be discussed in a later section.

\section{Discharge}

The volumetric discharge, $Q$, or more commonly the equivalent mean crosssectional velocity, $V$, can be expressed in terms of hydraulic and channel geometric parameters in the form of several semi-empirical equations. The two 
most widely used are the Manning equation and the Chezy equation. The Manning equation is:

$$
V=\frac{1}{n} r^{\frac{2}{3}} s^{\frac{1}{2}}
$$

where $n$ is a dimensional, empirical frictional coefficient and all variables must be expressed in MKS units. Tables of empirical values for $n$ may be found in texts on open channel flow (e.g., Henderson 1966), and vary from 0.025 to 0.150 for natural channels. The USGS (Barnes 1967) has published a we11illustrated report showing a variety of channels (different shapes, slopes, and sediment sizes) and their values of $n$ determined by calculation from gaged velocities.

The Chezy equation

$$
V=c(r S)^{\frac{1}{2}}
$$

is also empirical, but is often presented with $C=\left(\frac{8 g}{f}\right)^{\frac{1}{2}}$ because that form,

$$
V=\left(\frac{8 g r S}{f}\right)^{\frac{1}{2}}
$$

is the open-channel equivalent of the well-known Darcy-Weisbach pipe-flow equation. The resistance coefficient, $f$, known as the Darcy-Weisbach friction factor, is related to the roughness of the channel bed and banks and to flow parameters (Vanoni 1975).

Values for $n$ (Limerinos 1970) and $f$ (Brownlie 1981) can be determined from measured bed roughness in natural channels. However, in alluvial-channel applications, the bed roughness measured is often the median bed-sediment size. Even in a straight, uniform channel, the bed roughness is a function both of sediment roughness and bedform roughness. Studies have shown (e.g., Foley 1975) that the ratio of bed roughness, $f$, to flat-bed roughness, $f^{\prime}$, is: 


$$
\begin{aligned}
& \left(\frac{f}{f},\right)=1 \text { for flat beds, } \\
& 1 \leq\left(\frac{f}{f},\right) \leq 2 \text { for antidunes, and } \\
& \left(\frac{f}{f},\right)>2 \text { for ripples and dunes. }
\end{aligned}
$$

Specific methodologies discussed below address these relations in more detail.

\section{QUANTIFYING INDIVIDUAL PARAMETERS}

Paleohydrologic studies of surface waters are usually conducted for the purpose of estimating the maximum discharge (or maximum flow depth) that has occurred in a particular stream channel. Examination of the equations in the previous section shows that surface-water paleohydrologic methodologies stem from combined field and analytical techniques for determining the flow depth, width, cross-sectional shape, friction slope, and resistance coefficient. An additional goal of paleohydrologic studies is to establish the ages of prehistoric maximum flows to determine the statistical distribution of expected discharges in the current climatic regime, or to determine expected changes in peak discharges, which may result from a change to a pluvial or glacial climate.

Preservation of features that may be used to determine the values of these parameters is often serendipitous, and paleohydrologic investigations must necessarily be adapted to the specific field situation. For that reason, surface-water paleohydrologic investigations use flexible, ad hoc methodologies modified to suit the field problem. The flow equations discussed above provide the mathematical relations between parameters with values that may be determined by independent techniques and those for which no direct measurements are available.

Depth

Depth of flow in an existing channel or paleochannel is the most important parameter, in addition to the resistance coefficient, for calculating discharge. The accuracy of paleodischarge estimates for existing channels directly depends on the accuracy with which the paleodepths are determined or estimated. Techniques for determining or estimating paleodepth depend on the preservation of indicators of water-surface elevation or of sediments 
deposited in known relation to the water surface, or on less direct estimations that relate the competence of the flow to move large sediment to, among other parameters, the depth.

\section{High-Water Marks}

Benson and Dalrymple (1967) have discussed field techniques for indirect determinations of unmeasured stream discharge. An important aspect of these determinations is accurate measurement of high-water marks, and the techniques for identifying and evaluating indicators of water-surface level carry over into paleohydrologic studies. Floating debris deposited along the margins of a flow, "trim lines" dividing water-scoured banks below and unaffected banks above, and bent grass or other vegetation are principal indicators of watersurface elevation for studies of modern, ungaged flows.

These indicators of water-surface elevation can be affected by slope instabilities, which cause estimated elevations to be too low. They can also be affected by surge and superelevation. Marks on the upstream sides of obstacles will tend to be too high, whereas those on the downstream sides will be too low. Similarly, marks on the outsides of bends will be too high, whereas those on the insides will be too low. For these reasons, Benson and Dalrymple cautioned that high-water marks be measured preferentially in relatively straight channels on stable surfaces parallel to the flow.

Few of the techniques discussed above are useful in general in paleohydrologic studies because high-water marks are transitory features in all climates, and especially in humid ones. However, Stewart and Bodhaine (1961) were able to reconstruct stages for the 1815 and 1856 floods on the Skagit River, Washington, from high-water marks on trees and canyon walls and from suspended sediment lodged in tree bark and in crevices in canyon sides. The general requirements for representative indicators of water-surface elevation remain the same for paleohydrologic studies, and are the criteria for evaluating field observations. Paucity of data may require that data from less-desirable locations for highwater marks be used; Benson and Dalrymple's guidelines provide a basis for evaluating those data. 


\section{Ice-Rafted Debris}

Although organic debris deposited during high-stage flows conceivably could be preserved long enough to be useful for paleohydrologic studies, the literature has provided no examples unassociated with slack-water sediment deposits (to be discussed below). Inorganic debris is more likely to be preserved, but usually does not float unless carried on or within floating ice. "Erratics" deposited from free-floating or grounded ice can provide excellent, long-lived markers. The highest erratics beyond glacial limits are usually accurate high-water marks if Benson and Dalrymple's evaluation criteria are met. Ice-rafted erratics provide a major source of high-water marks in studies of the Channeled Scablands of the Columbia Plateau (e.g., Fryxell and Cook 1964; Baker 1973). However, Baker (1973) pointed out that ice-rafted erratics in the Channeled Scablands were usually concentrated in areas where floodwaters were ponded, and are lacking in more uniform flood reaches where open-channel flow theory applies.

\section{Eroded Channel Margins}

The highest indication of erosion by a flood flow, or the highest base of a flood-cut scarp, is a minimum elevation for the water surface. For example, Bretz (1928) attempted to estimate flow depths of floods in the Channeled Scablands on the basis of scarps eroded in loess or on the highest scabland eroded in basalt. For paleohydrologic purposes, this analog of the trimlines used in estimating water-surface elevations for modern floods is of limited accuracy. In the case of Bretz's measurements, for example, it is known that the actual water surface was at least $60 \mathrm{~m}$ higher than the bases of the loess scarps (Baker 1973).

\section{Minor Divide Crossings}

For the catastrophic floods of the Columbia Plateau, Baker (1973) found that the most consistent measurements of water-surface elevation were provided by the elevations of the smallest channels eroded where flood waters topped the usual drainage divides. The water surface was bracketed between elevations of the floors of the minor channels and those of the lowest nearby divides unmodified by flood flows. 


\section{Highest Flood Gravel}

Baker (1973) used the tops of flood-deposited gravel bars as indicators of minimum water-surface elevation. In the case of floods on the Columbia Plateau, these gravel bars were covered by flows of unknown depth and give water-surface elevations no more reliable than those indicated by eroded channel margins.

However, investigations in less-catastrophic floods have suggested that the highest flood gravels are not always unreliable indicators of water-surface elevation. For example, Stewart and LaMarche (1967) reported that the crests of natural, boulder-mantled levees formed during the flood of December 1964 on Coffee Creek, California, were up to $3 \mathrm{~m}$ above the channel bed and only 0.5 to $1 \mathrm{~m}$ below the flood high-water marks. Vessell (1977) found that the tops of some boulders up to $2.3 \mathrm{~m}$ in diameter deposited on levee or "boulder berm" crests in floods on the Rio Guacalate, Guatemala, were exposed above flood high-water marks. Vessell also found cobbles up to $20 \mathrm{~cm}$ in diameter deposited on a bridge deck approximately $4 \mathrm{~m}$ above the bed of the Rio Guacalate and very near the water-surface elevation of the flood reconstructed from conventional high-water marks discussed above.

The boulder berms on the Rio Guacalate were deposited in a diverging reach downstream of a flow constriction (Vessell et al. 1977). This suggests (Foley et al. 1978) that nonfrictional energy dissipation in the form of macroturbulent kolks (Matthes 1947) may have been the mechanism by which large boulders were deposited on the tops of the berms. Gary Parker suggested (written communication, 8 September 1978), based on laboratory experiments, that the boulder berms could have been formed by gravel-bar migration. However, Vessell (1977) showed that the boulders could have been transported in the deeper channels (necessary for entrainment by kolks) but not by the flows across the berm crests. Parker's observations may apply to formation of boulder berms in more uniform reaches, and may explain the formation of some of the bars observed by Stewart and La Marche (1967), Fahnestock (1963), and Scott and Gravlee (1968). 
Foley et a1. (1978) and Baker (1973) suggested that macroturbulent transport of boulders is most likely in diverging stream reaches where nonfrictional energy dissipation is important. For this reason, the water-surface elevations gained from observations of boulder berms, while more reliable than those from gravel bar elevations in more uniform stream reaches, are usually in flood reaches, which are less available for analysis, as described above. Thus, gravel deposits can be long-lived, desirable indicators of water-surface elevation. Additional uses of gravel deposits in paleohydrologic estimates will be discussed in later sections.

Slack-Water Deposits

Gravel and boulder deposits useful in reconstructing water-surface elevations depend on the supply of large sediment sizes to the paleoflows and on the ability of the paleoflows to transport the coarse sediments to potential sites of deposition. Further, as was discussed above, meaningful water-surface elevations derived from gravel deposits or boulder berms may require sediment transport mechanisms that are not operative on a large scale in the more uniform channel reaches suitable for analysis. Recent investigations (Patton, Baker and Kochel 1979: Kochel and Baker 1982) have used slack-water deposits--relatively fine-grained sediments that accumulate in areas of reduced flow velocity during floods--to estimate water-surface elevations of flood flows.

Kochel and Baker (1982) found that main-stem floods on streams in west Texas often follow flood peaks on tributaries, resulting in late-stage surges up the tributary valleys. These surges deposit the finer-grained detritus carried primarily as suspended load, and often cap such deposits with a layer rich in floating organic debris. If the slack-water deposits are preserved from erosion by floods on the tributaries, a layered sequence of deposits can accumulate with each layer representing deposits from a flood on the main stem that overtopped previous slack-water deposits. The organic cap typical of each deposit allows separation of sedimentation events and provides material suitable for radiocarbon dating.

As in the case of gravel bars, the slack-water deposits are covered by an unknown depth of water during deposition. However, by comparing water-surface 
estimates based on slack-water deposits with gaged data for floods on the lower Pecos River in 1954 and 1974, Kochel and Baker (1982) found that flow depth estimates were only about $10 \%$ too small. That is, slack-water sediment heights were usually 2 to $3 \mathrm{~m}$ below the water surface for peak flood stages of approximately $30 \mathrm{~m}$. This relation between slack-water sediment elevation and peak flow elevation probably is a function of flood duration, suspended sediment size, and magnitude of the flood and would not apply to channels other than that of the lower Pecos without independent corroboration.

\section{Evaluation}

Discussions in the above descriptions of water-surface indicators have concentrated on the reliability and utility of each technique for paleohydraulic analyses. These range from very good for minor divide crossings and sediment lodged in canyon-wall crevices to qualitative for the bases of flood-cut scarps. These discussions have not addressed the relationship between the water-surface elevation of a paleoflow and its depth.

For a water-surface elevation for a paleoflow in an existing channel to be related to the flow depth, it must be assumed that: 1) the water-surface indicator be reliable as discussed above; 2) the present channel be representative of the channel during the flood, with no significant aggradation or degradation during or after; and 3) the water-surface indicator represents flows in the present channel. Significant degradation and aggradation of an alluvial-channel bed during flood-wave passage has been proposed by, for example, Leopold, Wolman and Miller (1964). However, Foley (1978) has shown that such behavior is probably not a problem in the relatively straight, uniform reaches that are most desirable for paleohydrologic analyses. The relationship of paleoflow high-water marks to the present channel can be more difficult to determine. For example, a water-surface indicator above stream terraces may simply indicate a flood that overtopped the terraces, or may suggest that significant channel incision has occurred since the flood that made it. In such a case (e.g., Foley 1980b), careful field mapping, interpretation, and historical reconstruction must be performed before the flow geometry can be determined from remaining evidence. This process is almost mandatory for work with Quaternary paleohydrology because enough time has elapsed so that the above assumptions are seldom valid. 


\section{Direct Depth Determination}

Several techniques are available to estimate depth of flow directly from features of channel deposits. These are subject to more uncertainties for estimating water-surface elevation than the better of the techniques discussed above. However, depth-estimation techniques can add an independent check on water-surface determinations in which the relation between the paleochannel and present channel is not clear. Further, the depth-estimation techniques are useful in cases in which water-surface indicators are missing or where the bounds of the former channel are missing or questionable.

Competence Estimates. The maximum size of sediment particle that an openchannel flow can transport can be expressed as an empirical function of the shear stress (e.g., Vanoni 1975; Blatt et al. 1980). Typically, such relations provide a critical shear stress for initiation of motion of particles on a flat, alluvial bed composed of like-sized particles. Often, relations are further simplified by assuming that the particles have the same density of quartz and are immersed in water of $20^{\circ} \mathrm{C}$. Baker (1973), Baker and Ritter (1975), and Foley (1977) have suggested that large particles (e.g., boulders) exposed on a bed of smaller particles are moved at lower shear stresses than predicted by common shear-stress criteria. Baker and Ritter (1975) derived an empirical relation for particle size versus mean shear stress for coarse bedload material transported in rivers which, when inverted and restated in consistent units (Foley 1980b), gives:

$$
d=\frac{3.07}{\rho g S} d_{s_{\max }} 1.85,
$$

where $d_{s_{\max }}$ is the maximum sediment intermediate diameter and $d$ and $d_{s_{\max }}$ are in $\mathrm{cm}, \rho$ is in $\mathrm{gm} \mathrm{cm}^{-3}$, and $\mathrm{g}$ is in $\mathrm{cm} \mathrm{s}^{-2}$. John $\mathrm{E}$. Costs (University of Denver, written communication dated 4 October 1982) has suggested that simple algebraic manipulation of Baker and Ritter's regression equation, as done by Foley (1980b) may give a different relation than generation of a separate regression equation using depth as the dependent variable and shear stress and particle size as independent variables. The effect of this different approach on Equation (5.8) has not been determined because it requires obtaining and replotting Baker and Ritter's original data and performing a new regression analysis, which could not be accomplished within the time available. 
Use of Equation (5.8) to determine paleodepth assumes: 1) the boulders were transported as fluvial bedload, 2) the boulders sampled were the largest that the flow could transport, 3 ) the boulders were transported across a flat bed of generally smaller particles, and 4) the boulders sampled are in the same location in which they were deposited. Foley (1980b) used the above relation to estimate flow depths in an abandoned glacial outwash channel. To mitigate spurious determinations caused by ice-rafted debris, the $d_{s_{\max }}$ used for each estimate was the average intermediate diameter of the ten largest boulders at locations beyond the former glacier margins. The sediment source was glacial debris, which assured a supply of boulders for transport by the stream of sizes large enough to assume that the largest were of the maximum size that the stream could carry. In studies of the Channeled Scablands (Baker 1973), this assumption cannot be made even for boulders of several meters diameter.

Theoretically more-reliable competence estimates can be made for the special case of coarse-facies segregates in deposits from antidune-regime flow. Flow regimes are discussed in more detail below. The important point here is that subregularly spaced clusters of coarse, sometimes imbricate, gravels in the deposits of steep streams transporting coarse bed materials are of ten relict antidune bedforms called transverse ribs (Rust and Gostin 1981) or bedload dropout armor (Foley 1977). Foley (1977) has shown in laboratory experiments that such deposits form from the largest bedioad particles that a flow can transport by "normal" (i.e., not macroturbulent) fluvial processes over a flat bed by deposition on the upstream sides of growing antidunes. Thus, they demonstrate that all of the assumptions necessary for the use of competence estimates of paleodepth have been met. In addition, as is discussed below, the transverse ribs given an estimate of antidune wavelength that can be used in additional paleohydrologic estimates.

Competence estimates in the vicinity and upstream of morainal debris from Pleistocene valley glaciers require more care in field measurements. Leopold, Wolman and Miller (1964), Baker (1974), and Foley (1980b) have illustrated some of the care that must be exercised in field measurements of maximum fluvial 
boulder sizes in outwash deposits downstream of glacial moraines. Upstream of terminal moraines, maximum boulder sizes in stream channels can no longer be assumed to have been transported by fluvial processes. However, a plot of water-surface estimates made along a stream reach from all boulders larger than a given size may suggest a dividing line between a "normal" population (fluvial?) and "outliers" (residual glacial erractics?). Figure 5.2 shows such a plot for all boulders larger than $1 \mathrm{~m}$ in maximum diameter in a $40 \mathrm{~m}$ reach of the Middle Fork of the Popo Agie River, Wyoming (M. G. Foley 1979, unpublished data). Competence estimates were made using Baker and Ritter's (1975) equation, and the dividing line shown in Figure 5.2 could be interpreted as a maximum watersurface elevation. Further work would be necessary in any such application to lend credence to the separation of fluvially and glacially transported boulders. For example, the presence or absence of a lithologic difference between the "normal" and "outlier" populations could suggest differences in availability of particle sizes between the two lithologies for glacial transport rather than different transport mechanisms, and would require mapping of joint spacings in the source areas to choose between the alternate hypotheses.

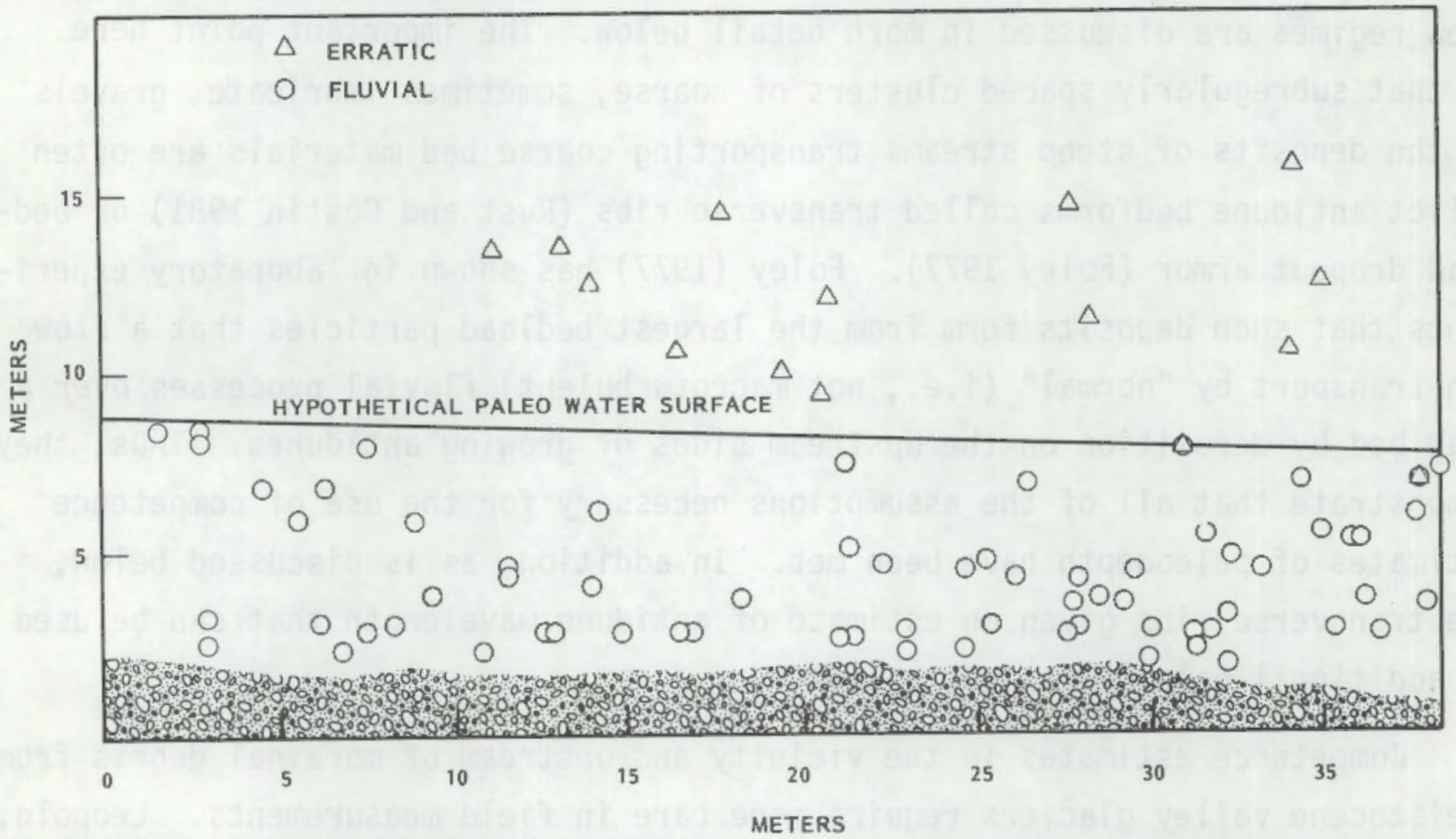

FIGURE 5.2. Estimation of Paleowater Surface in the Middle Fork of the Popo Agie River, Wyoming, by Calculating Paleodepths Competent to Move All Boulders Larger than $1 \mathrm{~m}$ Diameter Fluvially and by Oiscriminating Scattered Points (Glacial Erratics?) from Grouped Ones (Fluvial?) 
Estimates from Antidune Geometry. The beds of alluvial streams are rarely flat, and depending on the velocity and depth of flow may be deformed into a variety of migrating bedforms (see Figure 5.3), beginning with an initial flat bed at very low flow, followed by ripples, dunes, high-sediment-transport flat bed, and antidunes as the flow velocity increases (Vanoni 1975; Blatt et al. 1980). Ripples and dunes migrate downstream and produce cross-laminations in the bed sediment that have only tenuous and poorly understood relations with flow depth and velocity, although they can be used for estimating other paleochannel parameters, as is shown below. However, antidunes have geometry (amplitude and wavelength) that is closely related to flow velocity and depth (Kennedy 1961; Vanoni 1975). Hand (1969) has suggested that antidunes can be represented as trochoidal waves, and has related their wavelength, amplitude, and maximum face slope to the mean water depth and amplitude of the accompanying water waves. This technique is promising, although antidune cross-laminae are not as common as those of ripples and dunes, and tend to be less regular or complete (Middleton 1965).

Evaluation. Except for the use of antidune cross-laminae, all of the above techniques depend on some variant of a critical shear-stress criterion for the maximum size of fluvially transported particle. This technique is at its best for large particles moved across beds of smaller ones when Baker and Ritter's criterion is used. Even then (Baker and Ritter 1975, Figure 1), shear stress (hence depth if slope is known) may be in error by as much as a factor of 7 for $10 \mathrm{~cm}$ cobbles, and by a factor of 2 for $1 \mathrm{~m}$ boulders. Baker and Ritter suggested that the effect of hydrodynamic lift was not considered explicitly in empirical determinations of critical shear stress. Thus, large particles (relative to those around them) in relatively shallow flows will have lift forces proportionately larger than in the experimental determinations, whereas those submerged in very deep flows with small velocity gradients will have proportionately smaller lift forces.

Foley (1980b) found that two water-surface elevations on the same crosssection determined from Baker and Ritter's relation differed by less than $4 \mathrm{~cm}$ for water depths of 1 and $2 \mathrm{~m}$, This precision of 2 to $4 \%$ may have been 


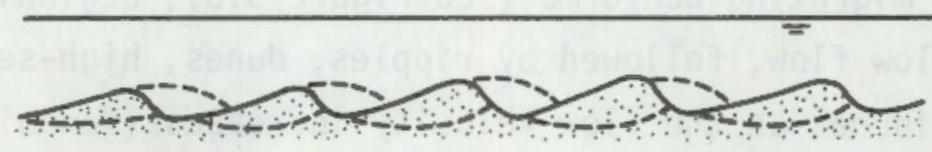

(a) RIPPLES

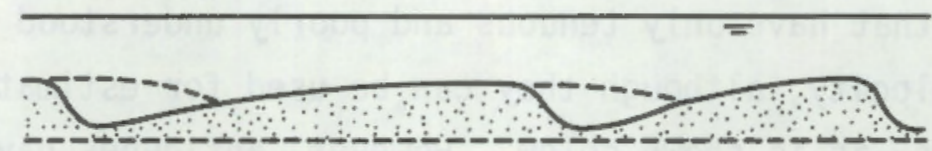

(b) SAND WAVES

LOWER

FLOW

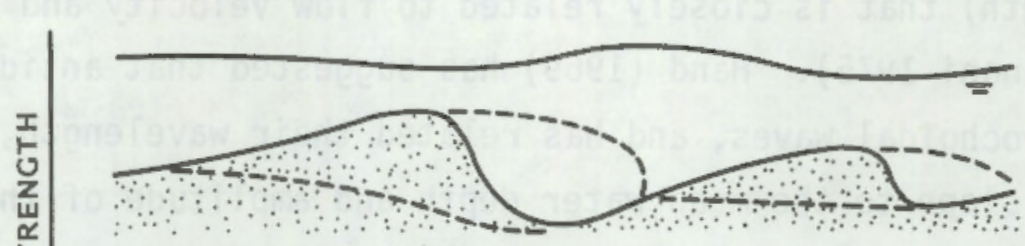

(c) DUNES (MEGARIPPLES)

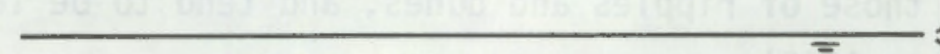

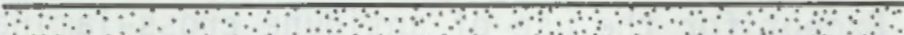

(d) PLANE (FLAT) BED

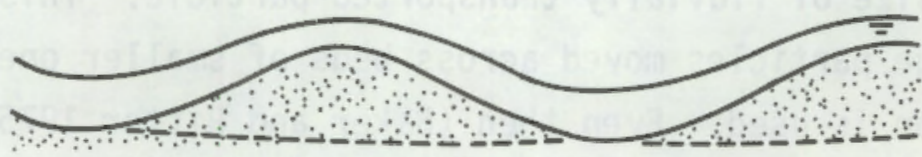

UPPER

(e) ANTIDUNES

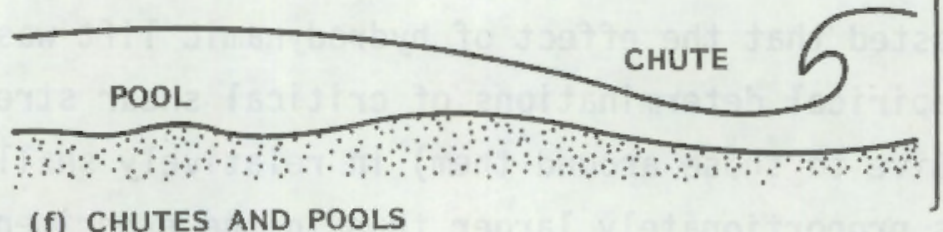

(f) CHUTES AND POOLS

FIGURE 5.3. Types of Bedforms in Quasi-Equilibrium Unidirectional Flows. Dashed lines indicate zones of flow separation. Not to scale. 
accidental, considering the relative crudity of the technique, and probably does not lend credibility to the accuracy of the method in general.

Helley (1969) derived a quasi-deterministic initiation-of-motion criterion for boulders on beds of smaller particles, based on hydrodynamic lift and drag, and tested it against field measurements. Helley considered that the boulders were tri-axial ellipsoids with intermediate axes inclined upstream between 0 and $25^{\circ}$ (see Figure 5.4), short axes upward, and long axes horizontal and normal to the flow. Critical bottom velocities (i.e., at a distance of 0.63 times the short axis above the bed) calculated from the theoretical analysis and measured for 34 boulders in Blue Creek, California, were within $10 \%$ for $47.1 \%$ of the measurements, 11 to $20 \%$ for $23.5 \%$ of the measurements, 21 to $30 \%$ for $20.6 \%$ of the measurements, and greater than $30 \%$ for $8.8 \%$ of measurements. The details of the analysis are beyond the scope of this report. However, Helley's ignoring the geometric effects of upstream inclination of the intermediate axis resuits in a $24 \%$ error in calculated drag at an inclination angle of $25^{\circ}$. Further, it is not clear that the same velocity is appropriate for calculating lift and drag. Finally, although Helley's analytical technique holds promise for initiation-of-motion studies, the usefulness for paleohydrology is not as direct as criteria based on a critical shear stress. As is discussed below, estimation of the velocity profiles of sediment-laden flows is subject to great uncertainty. Thus, conversion of a relatively accurate critical bottom velocity based on Helley's analysis to a paleodepth or mean flow velocity may result in a potential order-of-magnitude error overall.

\section{Slope}

The methodologies discussed so far have assumed that the channel of interest is still in existence, and that water-surface or depth indicators (or both) allow reconstruction of the cross-section of the paleoflow. Two or more reconstructed cross-sections permit both the channel and water-surface slopes to be determined. The slope-area method, to be described below, is then used to calculate friction slope and paleodischarge. However, if the paleochannel has been destroyed, and paleohydrologic studies must be based on remnants of channel sediments, the determination of paleoslope is crucial to hydraulic calculations. 


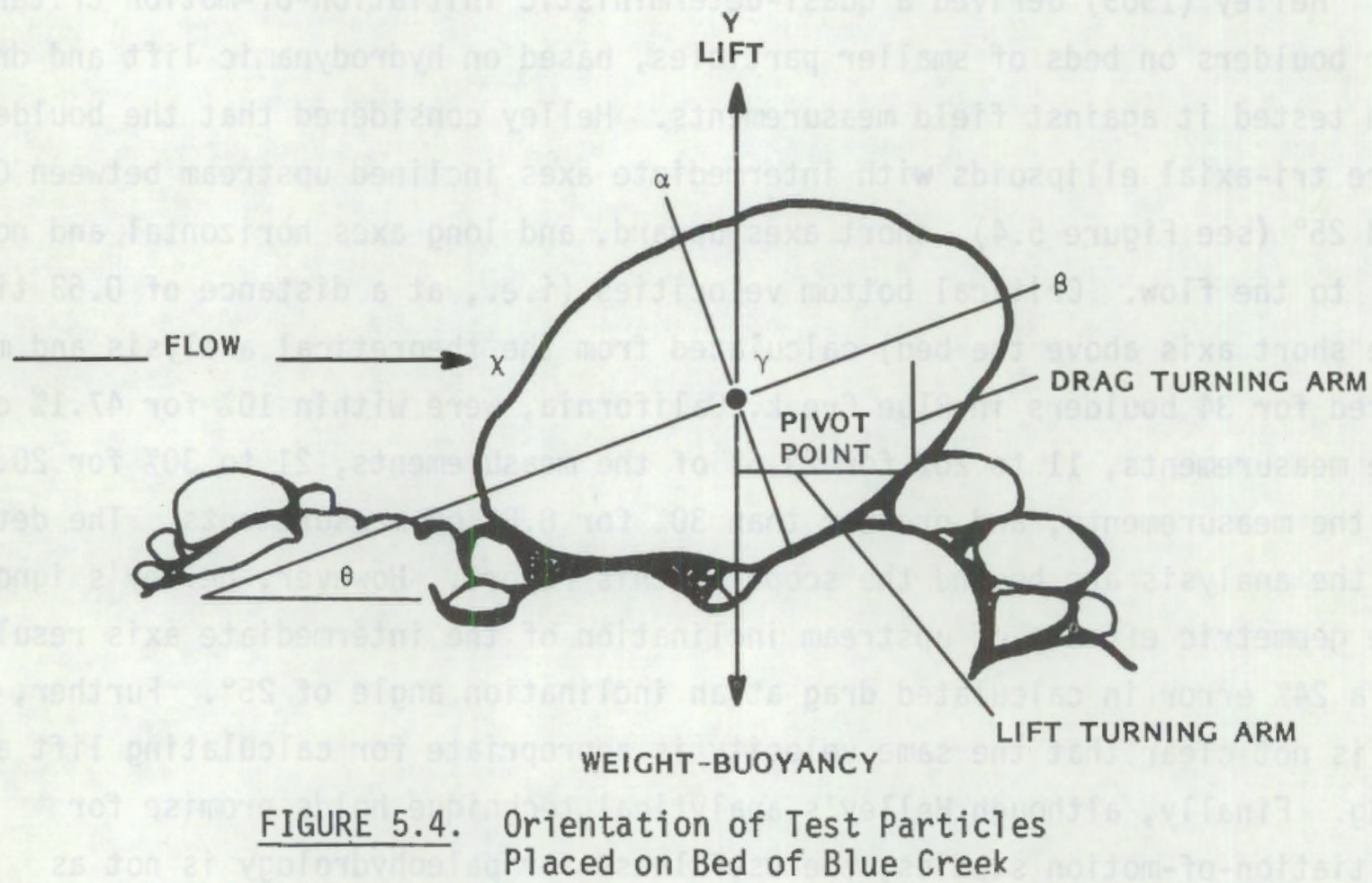

The critical shear-stress criterion for movement of large sediment particles yields only the product dS when $S$ is not known. Where transverse ribs are present, the wavelength of the antidunes that produced them is also preserved (Foley 1977; Rust and Gostin 1981). Kennedy (1961) has shown that the wavelength of antidunes is related to the mean flow velocity by the relation:

$$
V=\left(\frac{g L}{2 \pi}\right)^{\frac{1}{2}}
$$

Foley (1977) derived the relation:

$$
d=2.5 k_{s} \exp \left[\left(\frac{v}{u_{*}}-a_{r}\right) k\right] \text {, }
$$


where $k_{s}$ is the bed roughness length, $k$ is von Karman's constant, $a_{r}$ is a roughness coefficient (Bakhmetecff 1936), and

$$
u_{*}=\left(\frac{\tau_{0}}{\rho}\right)^{\frac{1}{2}}
$$

These two equations may be solved simuitaneously for d. However, the "constant" $k$ may vary from 0.2 to 0.4 , depending on the concentration of suspended sediment in the flow (Vanoni 1975). A $10 \%$ error in $\mathrm{k}$ results in a $100 \%$ error in $\mathrm{d}$ as determined by this method, suggesting that it should be used for order-ofmagnitude calculations only (Foley 1977). However, Coleman (1981) has suggested, based on his experiments, that earlier findings were in error, and that the value of $k$ is independent of the amount of suspended sediment in open channel flow. Evaluation of Coleman's findings may prove that the technique suggested by Foley (1977) is subject to less inherent error caused by variable $k$ than had been suspected previously.

Other techniques for determining paleoslope require the estimation of former valley cross-sections from the geometry of tributary streams or preserved remnants of peripheral parts of the former valley. Matthes (1930), in his classical study of the Yosemite Valley, reconstructed multiple Pleistocene positions of the Merced River by projecting the profiles of tributary streams in hanging valleys across the Yosemite Valley. Multiple reconstructions were possible because several graded tributary profiles were preserved between knickpoints in the bedrock hanging valleys. Foley (1980b) used remnants preserved under glacial till to reconstruct a valley profile at the time of diversion of the Dearborn River, Montana, and a later profile proiected from valley remnants buried by a younger till. These techniques clearly suffer from the uncertainty associated with the projection of curvilinear features over distances of a kilometer or more. However, several determinations made along a reach of tens of kilometers should mitigate the effects of local errors.

Width

The cross-section of a paleoflow in an existing channel can be determined by surveying the channel and estimating the flow depth somewhere along that 
cross-section as described above. Uncertainty is introduced by post-flow changes in the banks, such as slumping and landsliding or deposition of near-bank colluvial material. Further uncertainty can result from superelevation of flows in curved reaches. However, these uncertainties can be avoided by careful selection of cross-sections in relatively straight reaches away from areas of postflow erosional or depositional activity.

However, when the paleochannel is missing, or as in the case of the Missoula floods, was ill-defined when active, a quantitative estimate of paleowidth is difficult and subject to large uncertainties. Schumm (1968) estimated the widths (and bankfull depths) of buried prior stream channels of the Murrumbidgee River in Australia from detailed cross-channel stratigraphy (Figure 5.5).

Cotter (1971) estimated the width and depth of channels in which sands of the Late Cretaceous Ferron Sandstone were deposited using stratigraphic and textural data. Cotter assumed (based on Moody-Stuart 1966) that bankfull depth in the meander bends was equal to the thickness of the intervals of epsilon cross-stratified point bar sandstones. Further (also based on Moody-Stuart 1966), he estimated paleochannel width as 1.5 times the width of the point bar sandstone. Cotter then "adjusted" paleochannel depth downward somewhat to describe the depth of a straight reach, and derived a width-depth ratio of 12 for the straight paleochannel. This value compared with a width-depth ratio of 8 determined by measuring the silt-clay content of the "bed" and "banks" in thin-section and using Schumm's (1960) relation for alluvial channel geometry as a function of sediment type.

The $50 \%$ discrepancy between Cotter's (1971) width-depth ratios calculated by independent methods is probably a good indication of the uncertainty of paleowidth determinations. Cotter's direct estimate of width may have been in error by tens of percent. His direct estimate of depth would have had a similar uncertainty, although the use, when possible, of the more accurate techniques described in a previous section could have reduced that uncertainty. In addition, the estimates of silt-clay contents of the bed and banks could have been affected by the formation of authigenic quartz on the sand grains and of diagenetic clay by weathering of feldspars and mafic detrital grains. Schumm's (1960) hydraulic geometry relation depends on the detrital silt-clay 


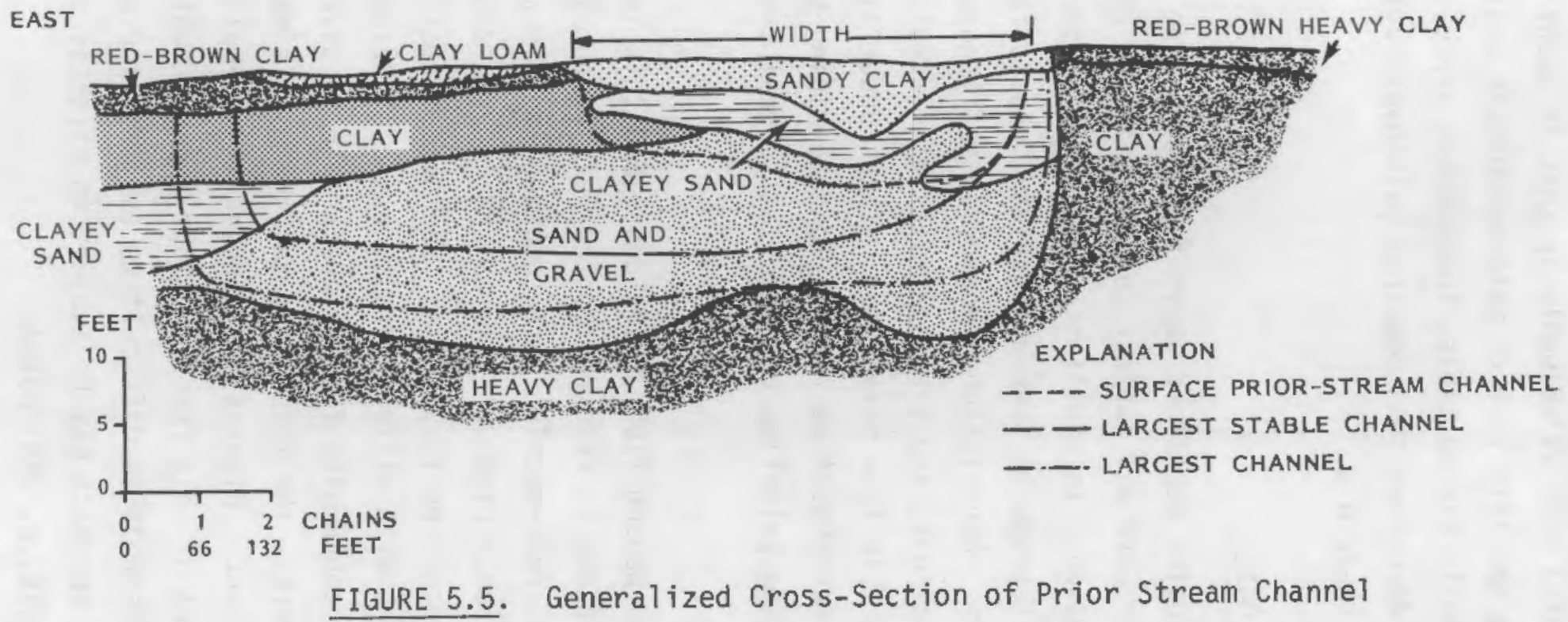


content and can be reasonably accurate (Foley 1975), but would be seriously affected by changes in silt-clay content induced by secondary mineralization.

Cotter's (1971) work is valuable in that it quantifies the uncertainty associated with a specific type of paleohydrologic analysis, and also demonstrates the necessity for multiple, independent approaches to paleohydrology. The next section describes some combined paleohydrologic techniques and gives some examples of their use.

\section{COMBINED METHODOLOGIES}

The methodologies described above for determining the paleovalues of hydraulic variables are all subject to uncertainties of varying magnitudes, as has been discussed. In addition, application of the flow equations to natural channels introduces some uncertainty because real, self-formed channels are seldom uniform. Nonfrictional energy losses induced by changes of channel shape, flow separations, and free overfalls will result in smaller discharge for the same geometric flow parameters. These uncertainties may be reduced by using multiple, independent approaches to determining values of hydraulic parameters and by making paleoflow estimates at several cross-sections.

\section{Slope-Area Method}

Dalrymple and Benson (1967) have described this technique in excellent detail, and the reader is referred to their treatment for actual application. In brief, several cross-sections are combined in this approach and treated with the Manning equation. High-water marks and in situ determinations of roughness coefficient are necessary input data. Each cross-section may be divided into several subsections with different roughness coefficients, and flow may be nonuniform (although converging flow is preferable to diverging flow). Given good high-water marks, the major uncertainty in this method is the estimate of roughness coefficient. Riggs (1976) presented a simplified slope-area method that requires input of only friction slope and high-water marks. Overall accuracy of these two methods is difficult to estimate for an ungaged site, although Riggs' simplified approach may be subject to slightly greater uncertainty. However, Riggs (1976, p. 285) noted: 
"Opinions range from claims of high accuracy to the comment of a prominent (unnamed) hydraulic engineer who was quoted by Henry Beckman (written communication 1924) as saying that, whenever results obtained by the slopearea method came nearer than 25 percent to the correct result, it was due either to accident or to a second choice of factors to use in the formula after the first choice had gone amiss. Fifty years later, wide differences of opinion as to the accuracy of the method still exist."

Despite differing opinions concerning its uncertainty, where data of sufficient quantity and accuracy are available the slope-area method is probabiy the most sophisticated technique of real use in most paleohydrologic studies. It is the basis for Baker's (1973) paleohydrologic studies of the Channeled Scablands and Vessell's (1977) study of the Rio Guacalate. In addition, it is often used in studies of maximum flood discharges in ungaged streams, or in rivers with gages that were destroyed by floods.

Other Combined Methodologies

Modern river studies employ more sophisticated techniques than those described above. Examples are the step-backwater analysis (Sherman 1976) and other computerized models such as HEC-2 (U.S. Army 1973). However, most paleohydrologic studies are data-limited, and the less-sophisticated techniques described above are adequate. 


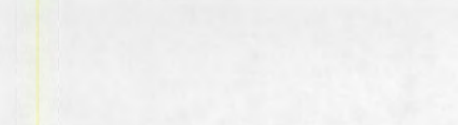

.

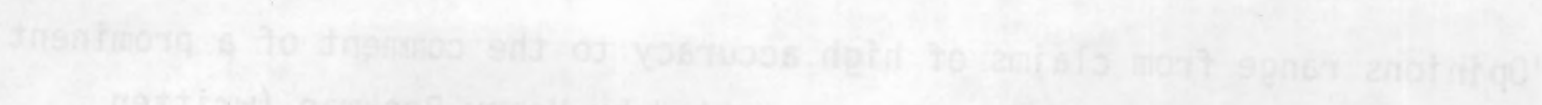

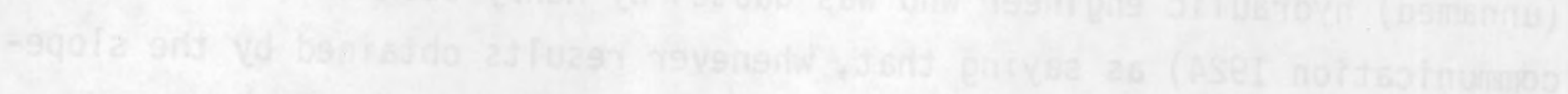

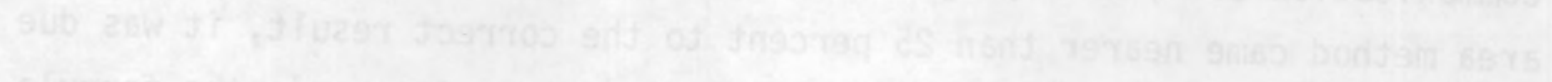

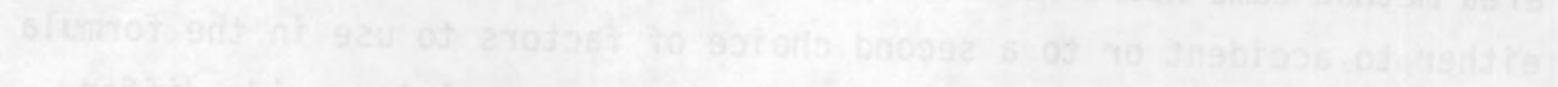

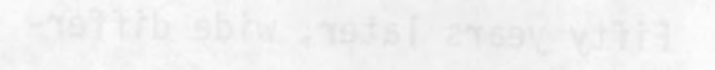

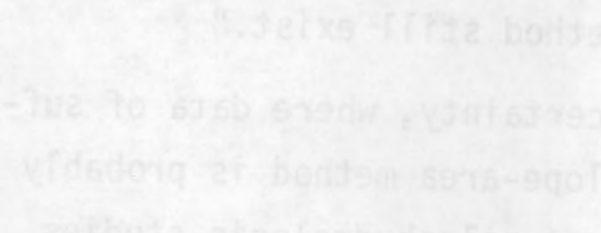
$\operatorname{con} 20$

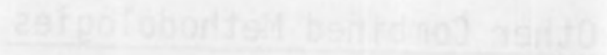

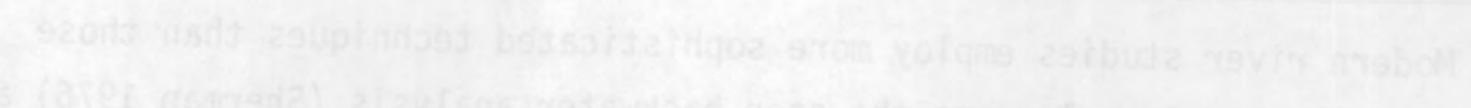

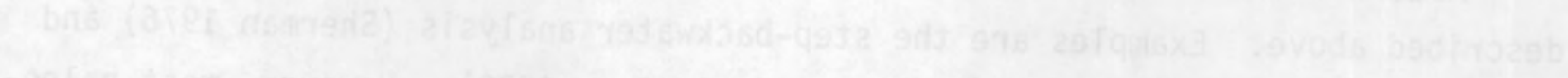

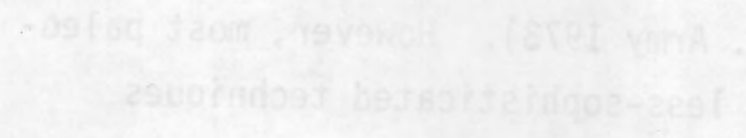




\subsection{GROUND-WATER METHODOLOGIES}

Ground-water studies are based on two different, but related, foundations: the sciences of geology, and the sciences of chemistry, physics, and mathematics. The hydrologist must understand geologic environments to understand the geologic influences on ground-water flow. He must also have a clear grasp of pnysics and chemistry to quantitatively examine ground-water flow, and of mathematics to provide a language that can describe the scientific observations.

Ground water as a science is usually traced to the work of a French hydraulic engineer named Henry Darcy. He developed an empirical law (Darcy's Law) which states that the velocity $(v)$ of a fluid through a uniform, porous medium is defined by the following equation:

$$
v=-k \frac{\Delta h}{\Delta l},
$$

where $h=$ hydraulic head,

$\ell=$ length, and

$K=$ hydraulic conductivity.

$K$ is a function of the medium and of the fluid flowing through it. Darcy's Law can be modified to describe the discharge, $Q$, of a given system:

$$
Q=-K i A \text {, }
$$

where $\quad i=$ hydraulic gradient,

$K=$ hydraulic conductivity, and

$A=$ area.

As previously stated, Darcy's Law is empirically derived. Other researchers relied more on the analysis of physical processes to understand ground-water flow. For example, Hubbert (Freeze and Cherry 1979) defined potential as "a physical quantity, capable of measurement at every point in a flow system, 
whose properties are such that flow always occurs from regions in which the quantity has higher values to those in which it has lower, regardless of the direction in space." This definition can be condensed to: the fluid potential $(\Phi)$ is equal to mechanical energy per unit mass of fluid:

$$
\Phi=g z+\frac{v^{2}}{2}+\int_{p_{0}}^{p} \frac{d p}{p},
$$

$$
\begin{aligned}
& \text { where } g=\text { acceleration of gravity, } \\
& z=\text { elevation, } \\
& v=\text { veiocity, } \\
& p=\text { pressure } \text {, and } \\
& \rho=\text { density of the fluid. }
\end{aligned}
$$

This potential is the sum of the work required to accelerate the fluid from zero velocity to velocity $=v$, and the work required to induce the fluid pressure. Given an incompressible fluid, and by substituting terms, we can derive the relation:

$$
\Phi=g h .
$$

In incompressible fluids of uniform density, fluid potential and hydraulic head are almost perfectly correlated.

The calculation for fluid flow must be coupled to the physical properties of the fluid flow and porous medium to describe the hydraulic aspects of ground-water flow. Given just six properties: density, viscosity, and compressibility for the fluid; and porosity, permeability and compressibility for the medium; all other parameters can be derived. This report is not - designed to discuss the various methods by which properties such as specific storage, transmissivity, and storativity can be calculated, but rather is designed to discuss how the physical parameters can be used to enhance knowledge and understanding of a given system. 
As in the case of surface-water paleohydrology, the technical foundations of the hydrology of contemporary ground-water systems must be applied to groundwater paleohydrology. If we can apply the formula of fluid transport in a ground-water system to a real data set, we may be able to better understand the evolution of that system and to predict its future. To do this, we should imagine a "typical" ground-water system. This system (Figure 6.1) consists of a land surface where rainfall enters the soil; a vadose or unsaturated zone where water percolates through to the water table; an unconfined aquifer; and a confined aquifer. Numerous physical parameters are measurable throughout the system. Isotopes and various chemical species are in the ground water and the air, and these same species are in the water in the atmosphere and the ocean. A relation exists between the concentrations of these species and time, and relations exist between parent and daughter isotopes. Interactions take place between the water, material, and medium as the water moves through the hydrologic cycle carrying these various isotopes and chemicals. From the relation. ships of these interactions we can develop an understanding of the system's past.

Paleohydrologic methodologies that deal with ground water are grouped into three categories: isotopic, physical and geochemical. Isotopic methodologies include the wide variety of analyses available on inert gases, parent/ daughter relationships, and isotope ratios. Studies that rely on physical evidence include interpretation of ancient karstic landforms through direct observation, location of paleosprings, and indicators of past water levels in exposed formations. Geochemical methodologies include kinetic studies, salinity and resistivity measurements, and ion ratio measurements. Most often, several of these methodologies are used in parallel to verify or improve the reliability of the conclusions. This section does not test the mechanics of each method, but rather presents the various techniques, their possible applications, and their limitations.

\section{ISOTOPES IN PALEOHYDROLOGY}

Eleven of the sources identified through the literature search were analyzed for this section on isotopes in paleohydrologic studies. Eleven sources obviously do not make an exhaustive list, but the techniques discussed in these 


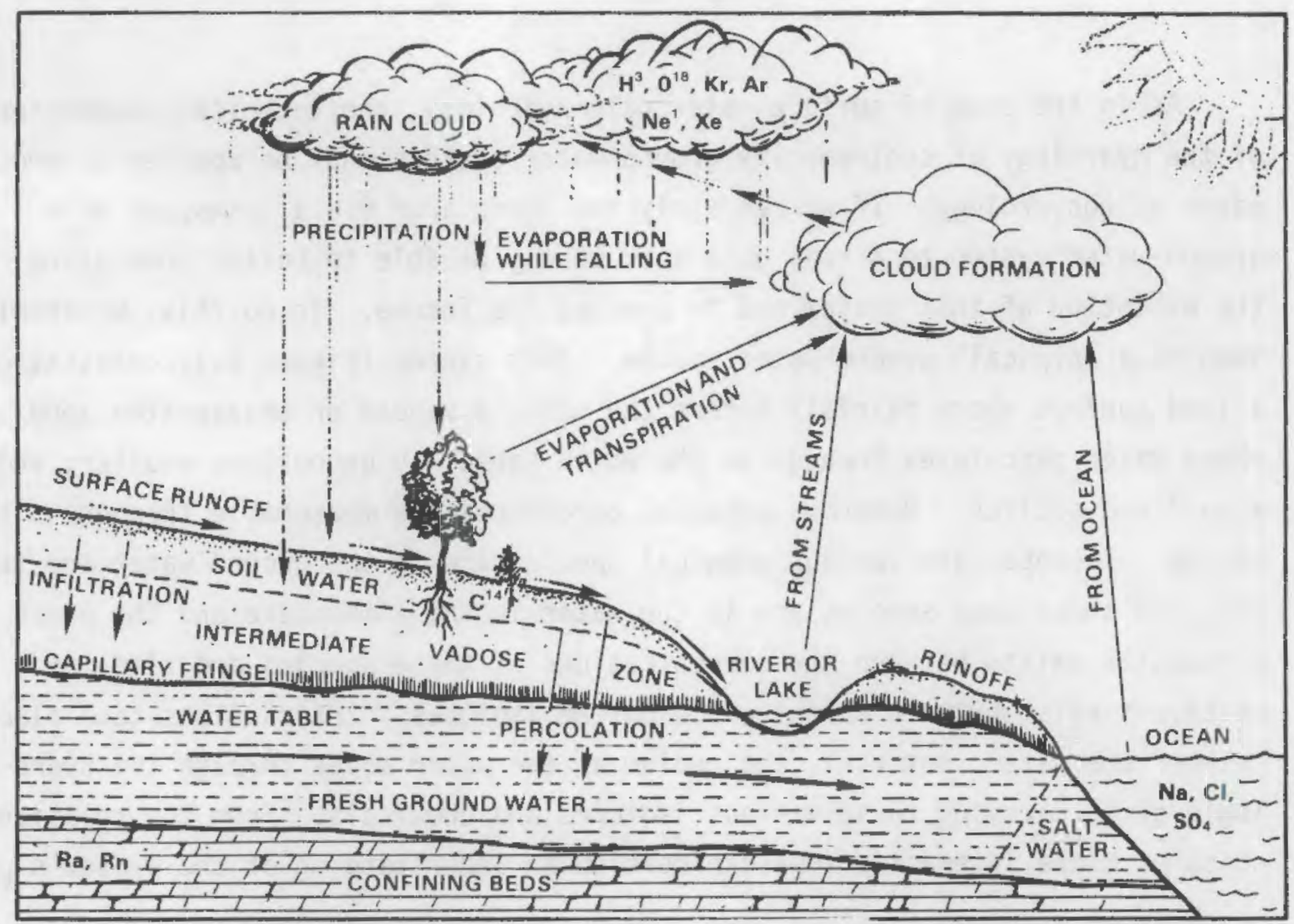

FIGURE 6.1. Ions and Isotopes in the Hydrologic Cycle

sources appear to include most of those used in present day research. Several prominant authors were queried during the research for this paper, including Peter Fritz of the University of Water100, Stanley Davis of the University of Arizona, and Robert Gilkeson of the Illinois Geological Survey. These researchers were asked to provide any insight into other techniques for paleohydrologic investigations, and their comments have been included in this chapter.

The isotopes that are most commonly used in hydrologic analyses are helium ( $\mathrm{He})$, krypton $(\mathrm{Kr})$, argon $(\mathrm{Ar})$, neon $(\mathrm{Ne})$, xenon $(\mathrm{Xe})$ radium $\left(\mathrm{Ra}^{226}\right)$, radon $(\mathrm{Rn})$, carbon $\left(\mathrm{C}^{14}\right)$, oxygen $\left(0^{18}\right)$, hydrogen $\left(\mathrm{H}^{3}\right)$ and $\mathrm{H}^{2}$ uranium $\left(\mathrm{U}^{235}\right.$ and $\left.\mathrm{U}^{238}\right)$, chlorine $\left(\mathrm{Ci}^{36}\right)$, selenium $\left(\mathrm{Se}^{79}\right)$, and iodine $\left(\mathrm{I}^{129}\right)$. Mazor (1976) divided this 1 ist of isotopes into six groups, creating a convenient format to discuss each of their applications in paleohydrologic techniques. These groups are discussed below. 
Stable hydrogen and oxygen isotopes, deuterium $\left(H^{2}\right.$ or $\left.D\right)$ and oxygen 18
$\left(0^{18}\right)$ have been used by many researchers to determine the origin of ground water, climate change, and ground-water movement. The oceans are the source for most of the precipitation that eventually becomes ground water. The hydrogen/oxygen stable isotope ratio in the ocean is constant. The clouds formed from water evaporating from the oceans will have a stable isotopic ratio of $0^{18}$ to $\mathrm{D}$. As the clouds move inland and increase in altitude, the heavier isotopes precipitate first, leaving the remainder of the cloud depleted in those isotopes. As a result, rain farther inland or at higher elevations becomes lighter and is distinct from rain at other locations. These distinctions become somewhat confused because of climatic effects, but annual averages tend to bear out the distinctive nature of waters at the different locations. Once the water infiltrates into the ground, these isotope ratios become fixed and the water has a distinctive "fingerprint" that indicates its origin.

Issar, Bein and Michaeli (1972) used $0^{18} / D$ ratios to confirm $C^{14}$ dating of fossil water in the Upper Nubian sandstone in the central Sinai. Fritz, et al. (1976) used the same techniques to distinguish the origin of waters to analyze storm runoff events. This technique has been used in numerous other applications, discussed in IAEA (1979).

Tritium occurs in the hydrologic cycle from both man-made and natural sources. Hydrogen $\left(H^{3}\right)$ is produced naturally by the interaction of cosmic rays and nitrogen. The natural concentration of tritium in the atmosphere was about 5 to 20 tritium units (TU) before atmospheric testing of thermonuclear bombs, which began in 1952. Because the half life of tritium is about 12.3 years, waters that were recharged before 1952 should have tritium concentrations on the order of 2 to 4 TU. After testing began, values for tritium in the atmosphere rose to $800 \mathrm{TU}$ in the northern hemisphere and to 60 in the southern hemisphere. This addition of tritium to precipitation allows researchers to group water into two age groups: water with tritium content less than 2 TU is pre1952; water with tritium content significantly higher is post-1952. Relative concentrations of tritium and carbon-14 can be used to further refine age dating of recharge water (Mazor 1976). Water with high tritium and high $\mathrm{C}^{14}$ 
concentrations is post-1952: water with low tritium but high $c^{14}$ concentrations is older than 1952 but younger than 30,000 years before present; water with low tritium and low $\mathrm{C}^{14}$ concentrations is older than 30,000 years before present.

Age dating of ground-water using $C^{14}$ is complicated by several mechanisms: 1) exchange and dissolution of old carbon from the soil and rocks in an aquifer, 2) fluctuations of natural carbon in rain, 3) additions of $c^{14}$ into the atmosphere from bomb testing, and 4) altering of atmospheric carbon by the burning of fossil fuels. Nevertheless, $c^{14}$ dating and testing is a common and useful tool for ground-water research. Mazor (1976) discussed the usefulness of $c^{14}$ dating when combined with tritium measurements. Geyh (1972) combined $C^{14}$ dating and tritium measurements to determine ground-water recharge rates in Central Europe and Brazil. A number of other applications are listed in IAEA (1976), along with the problems associated with those applications of $\mathrm{C}^{14}$ dating.

Radium-226 $\left(\mathrm{Ra}^{226}\right)$ is a product of the uranium-238 $\left(\mathrm{U}^{238}\right)$ decay series; in turn, it decays to radon-222 $\left(R^{222}\right)$. The geochemical path of these isotopes is: common igneous and sedimentary rocks contain $U^{238}$, which is incorporated into the mineral crystal lattices and is slightly dissolved by ground water. The $\mathrm{Ra}^{226}$ formed by the decay of the $\mathrm{U}^{238}$ is easily dissolved (especially in Cl-rich water), and the $\mathrm{Rn}^{222}$ formed by the decay of $\mathrm{Ra}^{226}$ is more easily dissolved. The dissolution of these isotopes is controlled by three factors: 1) time of contact of water to rock, 2) temperature (increased temperature increases solution), and 3) the amount of $\mathrm{Cl}^{-}$in the ground water.

Radium-226 can serve as a hydrological tracer by its presence in above normal concentrations ( 50 to $100 \mathrm{pCi} / \mathrm{l}$ ), indicating a high age; the ground water is trapped or is slow moving. Also, $\mathrm{Ra}^{226}$ can serve as a tracer in determining mixing of deep-seated and shallow ground water, an example being where high concentrations of both tritium and $\mathrm{Ra}^{226}$ are found.

Andrews and Lee (1979) discussed the use of $\mathrm{Rn}^{222}$ in the Bunter Sandstone in England. The amount of $\mathrm{Rn}^{222}$ in the groundwater of the Bunter Sandstone is attributed to the aquifer variability around the weil sampling points. The snort half-life and the water/rock contact time determine the amount of $\mathrm{Rn}^{222}$ that will be found in groundwater. If the water were to flow as fissure flow 
from a great distance, the amount of $\mathrm{Rn}^{222}$ would be reduced due to the low surface area of the fissures. If the water moves through the granular material of the aquifer, it can move only a short distance before the effects of halflife determine the $\mathrm{Rn}^{222}$ concentration arriving at a well point.

Helium-4 $\left(\mathrm{He}^{4}\right)$ is produced in the decay series of $\mathrm{U}^{238}, \mathrm{U}^{235}$, and $\mathrm{Th}^{232}$, which occurs in most igneous and sedimentary rocks. It is mobile and enters the water surrounding these rocks and is easily measured by mass spectrometry. The amount of $\mathrm{He}^{4}$ in the ground water is controlled by the length of time that the water is in cortact with the rock, and by the temperature of the system: the higher the temperature, the greater mobility of $\mathrm{He}^{4}$. Radiogenic $\mathrm{He}^{4}$ is a good ground-water tracer because the atmospheric contribution of $\mathrm{He}^{4}$ is negligible. Radiogenic $\mathrm{He}^{4}$ can be used as a tracer in several ways: high concentrations of $\mathrm{He}^{4}$ indicate older water; higher concentrations of $\mathrm{He}^{4}$ may indicate a high temperature environment at one time or another in the movement of the ground water: and high $\mathrm{He}^{4}$ concentrations found in conjunction with high tritium concentrations can be used to date and trace ground-water movement.

The atmospheric noble gases equilibrate very rapidiy with water, are temperature dependent, and are therefore useful as paleoclimatic indicators. Mazor (1976) listed four uses for the noble gases in paleohydrology: 1) to demonstrate the meteroric origin of thermal waters; 2) to deduce the ambient paleotemperatures that prevailed in the recharge area; 3) as a prospecting tool to determine thermal waters that are fed by superheated reservoirs versus those fed by medium-temperature reservoirs; and 4) as a tool for tracing steam production in geothermal fields.

Rozanski and Florkowsi (1979) described a specific technique for dating ground water using krypton-85 $\left(\mathrm{Kr}^{85}\right)$. This technique requires the collection of a 200- to 300-1iter sample of water, heating it, and spraying it in an evacuated chamber to collect the gases. Higher concentrations of $\mathrm{Kr}^{85}$ indicate younger water, whereas lower concentrations indicate water that has been out of contact with the atmosphere.

Loosli and 0eschger (1978) discussed a similar technique using argon-39 $\left(A r^{39}\right)$. This technique also requires a large water sample $\left(15 \mathrm{~m}^{3}\right)$ and is 
subject to even more contamination. Both the $\mathrm{Kr}^{85}$ and $\mathrm{Ar}^{39}$ techniques offer an alternative to tritium as a young water tracer.

Chlorine-36 is produced in the upper atmosphere by spallation of ${ }^{40} \mathrm{Ar}$. It is also produced in the subsurface by the following reaction:

$$
{ }^{35} \mathrm{Cl}+\mathrm{n} \longrightarrow{ }^{36} \mathrm{Cl}+\gamma
$$

If the production of ${ }^{36} \mathrm{Cl}$ has been constant in the atmosphere and the aquifer to be examined is well defined, an approximate age can be determined from a sample of 4 or more points. Davis (1979) estimates that ${ }^{36} \mathrm{Cl}$ will be useful for dating water between 50,000 and 1,000,000 years old.

Davis (1980) suggests selenium as a potential groundwater dating mechanism. The amounts of selenium that may be found in groundwater have not been determined yet, but its long half life and solubility in water make it a good candidate for groundwater tracing.

Iodine-129 $\left(\mathrm{I}^{129}\right)$ is another isotope that has potential for being a good ground-water age indicator. The primary source of $\mathrm{I}^{129}$ is cosmic ray activation of stable Xenon. The $I^{129}$ descends to the earth, mixes with the iodine carried with the water vapor from the ocean, and infiltrates into the groundwater system. Davis (1981) discusses problems caused by halite dissolution and source mixing but concludes that this isotope still has potential for groundwater dating.

\section{GEOCHEMICAL TECHNIQUES IN PALEOHYDROLOGY}

The dissolved ion concentrations found in groundwater vary considerably because of the many contributors to the system. Rain water is exposed to dust, atmospheric gases, sea spray, and man-made pollutants. This same water is exposed to the various components of the soils, plants that live in the soil, and the rock beneath the soil before it enters a ground-water system. Salt content can be altered by evaporative processes on open bodies of water and in the aerated zone of the soil. The exact nature and origin of a groundwater can be further complicated by the mixing and diluting of waters through fracture 
zones and aquitards. In spite of the problems in interpreting geochemical data, several paleohydrologic investigations have used geochmistry to interpret ground-water systems. Several of the sources identified through the literature search were analyzed for this section on geochemical techniques in paleohydrology. As in the section on isotope techniques, this list is by no means exhaustive, but it does give perspective to the types of work that are being performed.

Chebotarev (1955) examined thousands of chemical analyses of ground water from Australia and observed that the dominant anionic species change as ground water moves on a regional scale. The change generally follows the sequence:

$$
\mathrm{HCO}_{3}^{-}+\mathrm{HCO}_{3}^{-}+\mathrm{SO}_{4}^{2-}+\mathrm{SO}_{4}^{2-}+\mathrm{HCO}_{3}^{-}+\mathrm{SO}_{4}^{-}+\mathrm{Cl}^{-}+\mathrm{Cl}^{-}+\mathrm{SO}_{4}^{-}+\mathrm{Cl}^{-}
$$

The reason for this observation is apparent when one examines the availability and solubility of the sources of these ions. Bicarbonate $\left(\mathrm{HCO}_{3}{ }^{-}\right)$is more widely available in recharge areas but has lower solubility than sulfate $\left(\mathrm{SO}_{4}{ }^{2-}\right)$ or chloride $\left(\mathrm{Cl}^{-}\right)$. Whereas, chloride has very high solubility, but is usually not present in recharge areas because it has already been dissolved and transported. If recently recharged water is in contact with highly soluble minerals such as halite, the water will be dominated by chloride. On the other hand, very old water in crystalline rocks may be dominated by carbonate. Therefore, the evolution sequence given above is only useful when examined in light of the specific geochemical environment.

A decrease in redox potential has been noted as water flows through some aquifers. Germanov et al. (1958) were first to note this trend. Oxidation of organic matter is probably the cause (Freeze and Cherry 1979). This phenomena does not occur universally but could be useful in distinguishing older water is some aquifers.

LeGrande (1958) presented one of the more simplistic applications of geochemistry to paleohydrology. Ground water taken from North Carolina wells was analyzed for sodium, calcium, silica, total dissolved solids, and pH. On the basis of the chemical and geologic analyses of the areas from which the samples were taken, a model was developed that was used to predict the geology of the 
source area for other ground-water samples. This analysis divided the water of North Carol ina into those found in igneous and metamorphic rocks. Those waters with the higher concentration of minerals and higher $\mathrm{pH}$ were found in the more mafic gneisses, diorites, and andesites. Those water analyses that showed lower $\mathrm{pH}$ and less hardness were characteristic of the igneous rocks. These simple techniques are easily applied to other situations.

Parker (1969) used similar techniques to determine the history of groundwater flows in the East Texas Basin. Chemically distinct water was traced by ionic composition. Parker's analysis was somewhat different in that he used Schoeller diagrams (Freeze and Cherry 1979) to distinguish variations in the ion concentrations in each of the waters analyzed. Schoeller diagrams can accommodate and display large amounts of data and can be used to check similarities or differences in data. Parker concluded on the basis of the rock composition of the area, the geologic history, and the water quality comparison, that the waters of the aquifers were mixed in the upper portion, whereas the waters in the lower portions of the aquifers were distinct.

Hem (1970) provided data on the likely sources of major, minor, and trace constitutents in both ground water and surface water. Chemical reactions which affect the occurrence of each species were discussed and many case histories were presented. He also discussed various methods of organizing and presenting water-chemistry data. Many of these methods are applicable to paleohydrologic studies because the chemical composition of ground water gives clues to its age and the minerals with which it has been in contact.

Issar, Bein, and Michaeli (1972); Kafri and Arad (1979); and Nathan and Fructer (1974) all used chemical relationships in their studies to infer the geologic history of water in various settings. Mazor (1976) discussed the use of multitracing and multisampling in hydrologic studies.

Geochemical techniques are commonly used in conjunction with isotopic techniques in studying a ground-water system. Egboka (1981) used the distribution of tritium to distinguish water recharged since 1953 in two shallow aquifers from 
older water in the same aquifers. The distribution of the stable isotopes oeuterium and oxygen-18 were used to determine areas of evaporation from the aquifer. This information was used simultaneously with chloride and sulfate distributions to identify areas of recharge and discharge. A plume of contaminated water caused by an abandoned landfill was also delineated from the chloride and sulphate distributions.

The geochemical techniques examined so far are based on the chemical composition of water in the aquifer. Clues to paleohydrologic conditions may also be found in the aquifer matrix. Deposition of minerals occurs when the water becomes supersaturated. This may be caused by changes in pressure or temperature, evaporation, or the dissolution of a more soluble mineral containing one of the precipitation reactants. Much study has been devoted to the formation of economically important ores through such processes (Barnes 1967). White (1968) noted that saline solutions will dissolve and transport some minerals that are practically insoluble in pure water. The occurrence and chemical composition of evaporite deposits are also useful in determining ancient patterns of surface drainage. Kazory et al. (1968) discussed the incidence of salt deposits in geologic time.

\section{U.S. Geological Survey researchers including Bill Back, Ivan Barnes,} Bruce Hanshaw and John Hem were contacted in order to identify new techniques and current areas of research which have not yet been published. Geopressured zones in the Gulf Coast area of the United States are being studied, and may yield information on ancient hydrologic conditions. Freon compounds have been introduced to the environment by mankind within the last few decades and may prove useful for dating and tracing of groundwater. A large amount of research is also being devoted to developing a better understanding of chemical processes in the aquifer. Reaction kinetics are being studied as well as the solubilities of minerals in complex solutions. These data are being applied to the development of numerical models which will predict the chemical composition of groundwater as it flows through a given system. 


\section{PHYSICAL TECHNIQUES}

Paleohydrologic ground-water methodologies based on physical evidence rely on the uniformitarian principles developed by geomorphologists. These principles are to apply the knowledge of the world as it exists today to the evidence observed in the geologic record. To this end, a number of researchers have been identifying past geologic conditions by comparing them to analogous conditions today.

For example, paleokarst landforms and their associated geomorphic records can be used to infer past ground-water conditions. Sinkholes, common karst landforms, may be divided into three general types according to the conditions under which they develop. Solution sinkholes are formed by the solution of a 1 imestone surface to form a depression. Collapse sinkholes are formed by subsurface solution and the subsequent collapse of the cave roof. A third type of sinkhole forms in thin-bedded limestones where the roof of a cave collapses incremental1y, forming a steep-sided hole or cenote. The shapes of the caves beneath the holes, and the relative smoothness of the sides of the sinkholes, can tell the history of ground-water fluctuations in the vadose zone. Karst landforms also include gullies and valleys with vertical heads and sidewalls and nearly flat floors, which occur along solution escarpments.

Stringfield, LaMoreaux and LaGrande (1974) examined karst landforms in both arid and humid terrains to determine the paleohydrologic regimes that formed them. Each of the areas examined in the arid zones have evidence that the karst formed during a more humid period. The extent of karstification and the geologic history as evidenced in the stream channel and shore sedimentary record were used to determine the hydrologic conditions of the past.

Bogli (1980) discusses the effects of corrosion on cave walls and the relation of corrosion to the presence of a phreatic surface in the cave system. Water that is not exposed to the atmosphere becomes neutral as it moves through the system, while water exposed to air absorbs $\mathrm{CO}_{2}$ and becomes acidic. The acidity or corrosive nature of this water is seen as lines in the sides of caves or in non-symmetrical cave passages. 
Schmidt (1976) also worked with carbonate solution systems to determine paleohydrologic conditions. His examination of the passages and fill materials in Laurel Caverns in Pennsylvannia enabled him to determine that the caverns formed under hydrologic conditions very similar to those currently found in the area.

Burdon and Al-Sharhan (1968) discuss a proposed investigation of the Damman 1 imestone aquifer in Kuwait. They discuss the use of aquifer pump testing to determine transmissivity values, $T$, for several areas. Paleokarstic features would have higher $T$ values. Borehole logs and resistivity and geochemical data were to be collected to complement the pump test data. No indication of a follow-on report was found in our bibliographic search.

White and Deike (1964) discuss the use of flute marks and scallop marks on cave walls as a means to determine direction and velocity of underground streams. They determined that the direction of flow and the gradients in a cave system were controlled in part by stream piracy and changes in base level.

Numerous other studies of karst landforms have been carried out using sedimentological, paleonotological, and speleological techniques. Very often this research is hidden within other publications and is not identified as "paleohydrologic" research. This portion of the report must, therefore, be assumed to be incomplete despite the manual search that was conducted (see Section 3.0).

Winograd and Doty (1980) describe both macroscale and megascale morphologies in the Ash Meadows and Death Valley areas that are indicative of fossil spring deposits. These morphologies include fossilized vegetation mats, tufas draped over existing topography, and tufa mounds. Calcite veins and strandlines are also indicators of paleo ground-water levels. They used these phenomena to develop a paleohydrologic description of the Nevada Test Site and the surrounding areas, and incorporated the resulting differences in boundary conditions (from the present ones) into a computerized flow model to estimate the differences in ground-water flow.

Other physical techniques that have been used in paleohydrologic studies are consolidation tests, grain-size distribution analyses, and petrographic 
analyses. Soderman and Kim (1970) examined the St. Clair till in southwestern Ontario to determine the causes of the discrepancies between the observed and predicted settlement rates of structures bedded in the till. They determined that the till was overconsolidated at depth because of groundwater lowering in the past. The ground-water lowering was inferred from staining of sediments by oxidation of iron.

\section{Summary}

Three groups of techniques have been identified as being applicable to ground-water paleohydrological studies. Those techniques using isotopes use transport phenomena and decay times to determine residence time and travel time for water. Geochemical techniques can be used to determine the recharge area or the types of materials that a ground water has flowed through. Physical techniques demonstrate visible changes in materials that result from the past action of ground water. Most paleohydrologic studies use a combination of techniques to determine past conditions. 


\section{REFERENCES}

Allord, G. J. and F. L. Scarpace. 1979. "Improving Stream Flow Etimates Through the Use of Landsat." In Satellite Hydrology. Am. Water Resources Assoc., Minneapolis, MN.

Andrews, J. N. and K. J. Lee. 1979. "Inert Gases in Groundwater from the Bunter Sandstone of England as Indicators of Age and Paleoclimatic Trends." J. of Hydrology. 41(3-4):233-252.

Baker, V. R. 1971. "Paleohydeology of Catastrophic Pleistocene Flooding in Eastern Washington." Geol. Soc. Am. Abstracts with Prog. 3:497.

Baker, V. R. 1973. "Paleohydrology and Sedimentology of Lake Missoula Flooding in Eastern Washington." Geol. Soc. Am. Special Paper No. 144, $79 \mathrm{p}$

Baker, V. R. 1974. "Paleohydraulic Interpretation of Quaternary Alluvium Near Golden, Colorado." Quaternary Research. 4:94-112.

Baker, V. R., ed. 1981. Catastrophic Flooding: The Origin of the Channeled Scabland. Dowden, Hutchinson and Ross, Inc., Stroudsburg, PA.

Bakhmeteff, B. A. 1936. The Mechanics of Turbulent Flow. Princeton University Press, Princeton, New Jersey.

Barnes, H. H., Jr. 1967. "Roughness Characteristics of Natural Channels." U. S. Geol. Survey Water Supply Paper No. 1849, 213 p.

Barnes, H. L., ed. 1967. 2nd Edition. Geochemistry of Hydrothermal Ore Deposits. John Wiley and Sons, New York, New York.

Benson, M. A. and T. Dalrymple. 1967. "General Field and Dffice Procedures for Indirect Discharge Measurements." In Techniques of Water-Resources Investigations of the United States Geological Survey, Book 3, USGS, Washington, D.C.

Bögli, A. 1980. Karst Hydrology and Physical Speleology. Springes-Verlay, Berlin, Heidelberg, New York.

Bray, D. I. 1973. "Regime Relations for Alberta Gravel-Bed Rivers." In Fluvial Processes and Sedimentation. Natl. Research Council of Canada, Ottowa, pp. 440-452.

Bretz, J. H. 1928. "The Channeled Scabland of Eastern Washington." Geographical Review. 18:446-477.

Bretz, J. H. 1969. "The Lake Missoula Floods and the Channeled Scabland." J. of Geology. 77:505-543. 
Burdon, D. J. and A. Al-Sharhan. 1968. "The Problem of the Palaeokarstic Damman Limestone Aquifer in Kuwait." Journal of Hydrology. 6:385-404.

Carr, M. H. 1971. "Formation of Martian Flood Features by Release of Water from Confined Aquifers." J. of Geophysc. Research. 84(B6):2995-3007.

Chebatarev, I. I. 1955. "Metamorphism of Natural Waters in the Crust of Weathering." Geochem. et Cosmochem. Acta. 8:22-48, 137-170; 198-212.

Cotter, E. 1971. "Paleoflow Characteristics of a Late Cretaceous River in Utah from Analysis of Sedimentary Structures in the Ferron." J. of Sedimen. Pet. 41(1):129-138.

Dalrymple, T. and M. A. Benson. 1967. "Measurement of Peak Discharge by the STope-Area Method." In Techniques of Water-Resources Investigations of the United States Geological Survey. Book 3, Chapter A2. U.S. Geol. Survey, Washington, D.C.

Davis, S. N. 1979. Progress Report: Confirma cory Research Related to Dating of Ground Water. Prepared for the U.S. Nuclear Regulatory Commission, Washington, D.C. Available from the Office of Nuclear Regulatory Research.

Davis, S. N. 1980. Progress Report: Confirmatory Research Related to Dating of Ground Water. Prepared for the U.S. Nuclear Regulatory Commission, Washington, D.C. Available from the Office of Nuclear Regulatory Research.

Davis, S. N. 1981. Progress Report: Confirmatory Research Related to Dating of Ground Water. Prepared for the U.S. Nuclear Regulatory Commission, Washington, D.C. Available from the Office of Nuclear Regulatory Research.

Deju, R. A. 1971. Regional Hydrology Fundamentals. Gordon Bard Breach, New York, NY.

Dury, G. H. 1965. "Theoretical Implications of Underfit Streams." Geol. Survey Prof. Paper No. 452-C.

Egbota, B. 1981. "Distribution Patterns of Bomb Tritium, Chloride, Sulphate, 0xygen-18 and Deuterium in Two Shallow Sand Aquifers." Geochemical Journal 15:305-314.

Foley, M. G. 1980a. "Hydrology." Geotimes. 25:30-31.

Foley, M. G. 1980b. "Quaternary Diversion and Incision, Dearborn River, Montana." Geol. Soc. Am. Bu11. 91, Part II:2152-2188.

Foley, M. G. 1977. "Gravel-Lens Formation in Antidune Regime Flow--A Quantitative Hydrodynamic Indicator." 3 . of Sed. Petrology. 47(2):738-746.

Foley, M. G. et al. 1978. "Bed-Load Transport Mechanisms During Flash Floods." In Proceedings of Conference on Flash Floods: Hydrometerological Aspects. pp. 109-116. American Meterological Society, Boston, MA. 
Freeze, R. A. and J. A. Cherry. 1979. Groundwater. Prentice-Hall, Inc., Englewood $\mathrm{Cl}$ iffs, $\mathrm{NJ}$.

Fritz, P., et al. 1976. "Storm Runoff Analysis Using Environmental Isotopes and Major Ions." In Interpretation of Environmental Isotope and Hydrochemical Data in Groundwater Hydrology, International Atomic Energy Agency, Vienna.

Fryxell, R. and E. F. Cook. 1964. "A Field Guide to the Loess Deposits and Channeled Scablands of the Palouse Area, Eastern Washington." Washington State Univ., Pullman, Lab Anthropology, Rept. Invesi. 27, 32 p.

Germanov, A. I., G. A. Volhov., A. K. Lisitsin, and V. S. Serebennekov. 1958. Investigation of the Oxidation Reduction Potential of Ground Waters." Acad. Sci. USSR, Moscow, Inst. Geol. Ore Deposits, Petrogr., Mineral, Geochem..

Geyh, M. A. 1972. "Basic Studies in Hydrology and C-14 and H-3 Measurements." Section II, Hydrogeology. In Inter. Nat. Geol. Cong., 24th Session, Ed., J. D. Gi11, pp. 227-236.

Hack, J. T. 1957. "Studies of Longitudinal Stream Profiles in Virginia and Maryland." U.S. Geol. Survey Prof. Paper No. 294-B, pp. 45-97.

Hand, B. M. 1969. "Antidunes as Trochoidal Waves." J. of Sedimen. Pet. 39: 1302-1309.

Helley, E. J. 1969. "Field Measurement of the Initiation of Large Bed Particle Motion in Blue Creek Near Klamath, California." U.S. Geol. Survey Prof. Paper No. 562-G, 19 p.

Hem, J. D. 1970. "Study and Interpretation of the Chemical Characteristics of Natural Water." 2nd Edition. U.S. Geological Survey Water-Supply Paper 1473.

Holtz, R. K. and V. R. Baker. 1979. "An Examination of Fluvial Morphological Characteristics of Western Amazon Streams from Appollo-Soyuz Photographs." In Satellite Hydrology. pp. 252-261, Am. Water Resources Assoc., Minneapolis, MN.

IAEA (International Atomic Energy Agency). 1976. Interpretation of Environmental Isotope and Hydrochemical Data in Groundwater Hydrology. IAEA, Vienna.

IAEA (International Atomic Energy Agency). 1979. Isotope Hydrology 1978 Vol. 11. IAEA, Vienna.

Issar, A., A. Bein and A. Michaeli. 1972. "On the Ancient Water of the Upper Nubian Sandstone Aquifer in Central Sinai and Southern Israel." J. of Hydrology. 17:353-374. 
Kafri, U. and A. Arad. 1979. "Current Subsurface Intrusion of Mediterranean Seawater--A Possible Source of Groundwater Salinity in the Rift Valley System, Israel." Journal of Hydrology. 44:268-287.

Kozary, M. T., J. C. Dunlap, and W. E. Humphrey. 1968. "Incidence of Saline Deposits in Geologic Time." Geological Society of America Special Paper 88.

Langford-Smith, T. 1959. "Deposition on the Riverine Plain of Southeastern Australia." Australian J. Sci. 22:73-74.

LeGrand, H. E. 1958. "Chemical Character of Water in the Igneous and Metamorphic Rocks of North Carolina." Economic Geology. 53:178-189.

Leopold, L. B., M. G. Wolman and J. P. Miller. 1964. Fluvial Processes in Geomorphology. W. H. Freeman, San Francisco, CA.

Leopold, L. B. and M. G. Wolman. 1960. "River Meanders." Geol. Soc. Am. Bull. 71:769-794.

Loos1i, H. H. and H. Oeschger. 1979. "Argon-39, Carbon-14 and Krypton-85 Measurements in Groundwater Samples." In Isotope Hydrology 1978 Vol. 11, International Atomic Energy Agency, Vienna.

Matthes, F. E. 1930. "Geologic History of the Yosemite Valley." U.S. Geol. Survey Prof. Paper No. 160, 137 p.

Nathan, S. and J. S. Fruchter. 1974. "Geochemical and Paleomagnetic Stratigraphy of the Picture Gorge and Yakima Basalts in Central Oregon." Geol. Soc. Am. Bull. 85:63-76.

Patton, P. C., V. R. Baker and R. C. Kochel. 1979. "Slack-Water Deposits: A Geomorphic Technique for the Interpretation of Fluvial Paleohydrology. " In Adjustments of the Fluvial System, Ed., D. D. Rhodes, pp. 225-253. Kendall-Hunt Pub. Co., Dubuque, IA.

Pels, S. 1964. "The Present and Ancestral Murray River System," Australian Geog. Studies. 2:111-119.

Riggs, H. C. 1976. "A Simplified Slope-Area Method for Estimating Flood Discharges in Natural Channels." J. Research U.S. Geol. Survey. 4(3): 235-291.

Rozanski, K. and T. Florkowski. 1979. Krypton-85 Dating of Groundwater." In Isotope Hydrology $1978 \mathrm{Vol}$. 11, International Atomic Energy Agency, Vienna.

Rust, B. R. and V. A. Gostin. 1981. "Fossil Transverse Ribs in Holocene Alluvial Fan Deposits, Depot Creek, South Australia." J. of Sedimen. Pet. 51:441-444. 
Schmidt, V. A. 1976. "The Paleohydrology of Laurel Caverns, Pennsylvania." Nat\}. Speoleol. Soc. Annu. Conv., Morgantown, W. VA., Annu. Conv. Guideb., Nat1. Speoleol. Soc., pp. 32-35.

Schumm, S. A. 1960. "The Shape of Alluvial Channels in Relation to Sediment Type." U.S. Geol. Survey Prof. Paper No. 352-B.

Schumm, S. A. 1963. "A Tentative Classification of Alluvial River Channels." U.S. Geol. Survey Circular No. 477, 10 p.

Schumm, S. A. 1968. "River Adjustments to Altered Hydrologic RegimenMurrumbridge River and Paleochannels, Australia." Geol. Survey Prof. Paper No. 598. 65 p.

Schurm, S. A. 1977. The Fluvial System. John Wiley and Sons, Inc., New York, NY.

Sherman, J. 0. 1976. Computer Applications for Step-Backwater and Floodway Analyses. U.S. Ge01. Survey Open File Report 76-499, Washington, D.C.

Soderman, L. G. and Y. D. Kim. 1970. "Effect of Groundwater Levels on Stress History of the St. Clair Clay Till Deposit." Canadian Geochemical Journal $7: 173$.

Stewart, J. E. and G. L. Bodhaine. 1961. "Floods in the Skagit River Basin, Washington." U.S. Geol. Survey Water Supply Paper No. 1527, 66 p.

Stringfield, V. T., P. E. LaMoreaux and H. E. LeGrand. 1974. "Karst and Paleohydrology of Carbonate Rock Terranes in Semiarid and Arid Regions with a Comparison to Humid Karst." Alabama Geol. Survey Bul1. 105:106.

Thomas, D. M. and M. A. Benson. 1970. "Generalization of Streamflow Characteristics from Drainage Basin Characteristics." U.S. Geol. Survey Water Supply Paper, No. 1955, 55 p.

U.S. Army. 1973. HEC-2: Water Surface Profile, Users Manual, U.S. Army Corps of Engineers, Hydrologic Engineerino Center, Davis, CA.

Vessel, R. K. 1977. Morphology, Hydrology, and Sedimentology of Rio GuacalateVolcanic Highlands--Guatemala. Unpub. M. A. Thesis, Univ. Missouri, Columbia, $144 \mathrm{p}$.

Vessel, R. K., et al. 1977. "Sedimentology and Hydrology of Flood Flows on the Active Volcano Fuego, Guatemala." Geol. Soc. Am. Abstr. with Prog. 9:1210-1211.

Way, D. S. 1978. Terrain Analysis. Uowden, Hutchinson, and Ross, Inc., Stroudsburg, PA. 
White, W. B. and G. H. Deike. 1964. "Preliminary Results on the Paleohydrology of Mammoth Cave and the Flint Ridge Cage System (Abstr.)." Geol. Soc. of Am. Spec. Paper No. 76, p. 320.

White, D. E. 1968. "Environments of Generation of Some Base-Metal Ore Deposits." Econ. Geol., 63:301-335.

Winograd, I. J. and G. C. Doty. 1980. "Paleohydrology of the Southern Great Basin, with Special Reference to water Table Fluctuations Beneath the Nevada Test Site During the Late Pleistocene." U.S. Geol. Survey Open File Report No. 80-569, $91 \mathrm{p}$. 


\section{BIBLIOGRAPHY}

Adamson, D. A., F. Gasse, F. A. Street and M. A. J. Williams. 1980. "Late Quaternary History of the Nile." Nature. 288(5786):50-55.

Agenbroad, L. D. 1967. Cenozoic Stratigraphy and Paleohydrology of the Redington-San Manuel Area, San Pedro Valley, Arizona. Dissertation, University of Arizona. University Microfilms, Inc., Ann Arbor, Michigan.

Agterber, F. P. 1967. "Paleocurrent Trend Analys is of a Delta in Bjorne Formation (Lower Triassic) of Northwestern Melville Island Arctic." J. of Sedimen. Pei. 37:852.

Alexander, D. 1981. "Threshold of Critical Power in Streams, Discussion and Reply." Geol. Soc. of Am. Bull. 92, Part I:310-312.

Allen, J. R. 1966. "On Bed Forms and Palaeoccurrents." Sedimentiology. $6: 153-190$.

Allen, J. R. L. 1975. "The Mechanics of Fluvial Deposition, with Particular Reference to the Problems of Palaeohydraulics." Quaternary News. (Glasgow) 1(15):4-5.

Allen, J. R. L. 1963. "Asymmetrical Ripple Marks and the Origin of WaterLaid Cosets of Cross-Strata:" Liverpool Manchester Geol. J. 3:187-236.

Allen, J. R. L. 1968. Current Ripples and Their Relation to Patterns of Water and Sediment Motion. North-Holland Publishing Co., Amsterdam.

Allen, J. R. L. 1971. "Transverse Erosional Marks of Mud and Rock: Their Physical Basis and Geological Significance." Sedimentary Geology. $5(3-4): 167-370$.

Allord, G. J. and F. L. Scarpace. 1979. "Improving Stream Flow Estimates Through the Use of Landsat." In Satellite-Hydrology, Am. Water Resources Assoc., Minneapol is, Mis.

Alvineri, J. 1978. "Contribution to Knowledge of Paleohydrology of Northeast Atlantic During Terminal Quaternary Period." Oceanology Aci. 1(1):87-98.

Alvineri, J., M. Caralp, C. Latouche, J. Moyes and M. Vigneaux. 1978. "The Paleohydrology of the Northeastern Atlantic During the End of the Quaternary." Oceanol. Aci. 1(1):87-98.

Anderson, R. E. 1969. "Notes on the Geology and Paleohydrology of the Boulder City Pluton, Southern Nevada." U.S. Geol. Survey Prof. Paper No. 650-B, pp. $35-40$. 
Andrews, J. N. and K. J. Lee. 1979. "Inert Gases in Groundwater from the Bunter Sandstone of England as Indicators of Age and Paleoclimatic Trends." J. of Hydrology. 41(3-4):233-252.

Arkhildeyeva, Y. 1974. "Paleohydrological Conditions of the Formation of Underground Waters of the Trans-Carpathian Downwarp." Geol. Geokhim Goryuch Iskop. (Kiev) 40:21-27.

Atkinson, T. C., D. I. Smith, J. J. Lavis and R. J. Whitacker. 1973. "Experiments in Tracing Underground Waters in Limestones." J. of Hydrology. 19(4):323-349.

Back, W. 1960. "Origin of Hydrochemical Facies of Ground Water in the Atlantic Coastal Plain." Internat. Geol. Cong., Copenhagen, 1960.

Back, W., R. N. Cherry, and B. B. Hanshaw. 1966. "Chemical Equilibrium Between the Water and Minerals of a Carbonate Aquifer." Nat1. Speleol. Soc. Bull. 28(3): 119-126.

Back, W. and B. B. Hanshaw. 1970. "Comparison of Chemical Hydrogeology of the Carbonate Peninsulas of Florida and Yucatan." J. of Hydrology. $10(4): 330-368$.

Bailey, R. J. 1967. "Paleocurrents and Paleoslopes--A Discussion." J. of Sedimen., Pet. 37:1252.

Baker, V. R. 1971. "Paleohydrology of Catastrophic Pleistocene Flooding in Eastern Washington." Geol. Soc. Am. Abstracts with Prog. 3:497.

Baker, V. R. 1976. "Hydrology of a Cavernous Limestone Terrane and the Hydrochemical Mechanisms of its Formation, Mohawk River Basin, New York." Empire State Geogram. 12(2):2-65.

Baker, V. R. 1971. Paleohydrology and Sedimentology of Lake Missoula Flooding in Eastern Washington. Thesis, Univ. of Colorado. Univ. Microfilms Internat., Ann Arbor, MI.

Baker, V. R. 1973. "Paleohydrology and Sedimentology of Lake Missoula Flooding in Eastern Washington." Geol. Soc. Am. Special Paper No. 144, 79 p.

Baker, V. R. 1974. "Paleohydraulic Interpretation of Quaternary Alluvium Near Golden, Colorado." Quaternary Research. 4:94-112.

Baker, V. R. 1978. "The Spokane Flood Controversy and the Martian Outflow Channels." Science. 202(4374):1249-1256.

Baker, V. R., Ed. 1981. Catastrophic Flooding: The Origin of the Channeled Scabland. Dowden, Hutchinson and Ross, Inc., Stroudsburg, PA.

Baker, V. R. and M. M. Penteado. 1975. "Sedimentology and Paleohydrology of Quaternary Fluvial Regime Changes, Colorado River, Central Texas." In Proc. Int. Sedimen. Cong. 9(1):19-22. 
Ballard, R. D. and E. Uchupi. 1970. "Morphology and Quaternary History of the Continental Shelf of the Gulf Coast of the United States." Bulletin of Marine Science. 20(3):547-559.

Bandyopadhyay, S. 1971. "Pebble Orientation in Relation to Cross-Stratification: A Statistical Study." J. of Sedimen. Pet. 41(2):585-587.

Barnes, I. and R. Benta11. 1968. "Water-Mineral Relations of Quaternary Deposits in the Lower Platte River Drainage Area in Eastern Nebraska." U.S.G.S. Water Supply Paper 1859-D.

Barnes, I. and J. R. O'Neil. 1969. "The Relationship Between Fluids in Some Fresh Alpine-Type U1tramafics and Possible Modern Serpentinization, Western United States." Geol. Soc. of Am. Bul1. 9-"1048-1960.

Barnes, I., J. B. Rapp, J. R. 0'Nei1, R. A. Sheppard, and A. J. Gude III. 1972. "Metamorphic Assemblager and the Direction of Flow of Metamorphic Fluids in Four Instances of Serpentinization." Contribution to Mineralogy and Petrology. 35:263-276.

Beard, J. H. 1969. "Pleistocene Paleotemperature Record Based on Plaktonic Foraminifers, Gulf of Mexico." Gulf Coast Assoc. of Geol. Soc. Trans. $19: 535-553$.

Becking, L.G.M., I. R. Kaplan, and D. Moore. 1960. "Limits of the Natural Environment in Terms of $\mathrm{pH}$ and Oxidation-Reduction Potentials: Journal of Geology. $68(3)$.

Benson, M. A. 1967. "General Field and Office Procedures for Indirect Discharge Measurements." In Techniques of Water-Resources Investigations

Benson, M. A. 1965. "Spurious Correlations in Hydraulics and Hydrology." In Proceedings of A.S.C.E. 91(Hy 4):35-42.

Biernacki, Z. 1975. "Holocene and Late Pleistocene Alluvial Sediments of the Vistula River Near Warsaw." Biul. Geol. 19:199-217.

Bijuduva, B. 1966. "Constance Des Directions Des Paleocurrents Dans Les Gres De Base Du Cambro-Ordovicien Sur Le Pourtour Du Hoggar." Cr Ac Sci D. 262:48.

Birkeland, P. W. 1968. "Mean Velocities and Boulder Transport During TahoeAge Floods of the Truckee River, California-Nevada." Geol. Soc. Am. Bull.
79:137-141.

Birks, H. H., M. C. Whiteside, D. M. Stark and R. C. Bright. 1976. "Recent Paleolimnology of Three Lakes in Northwestern Minnesota." Quaternary Research. 6:249-272.

Blake, W. P. 1902. "Lake Quiburis, An Ancient Pliocene Lake in Arizona." Univ. Arizona Monthly. 4:107-108. 
Boggess, D. H. and S. G. Heidel. 1968. Water Resources of the Salisbury Area, Maryland. Maryland Geol. Survey, Rept, Inv. No. 3, 69 p.

Bogomolov, G. V., A. A. Kartsev, G. P. Yakobson and Y. G. Bogomolov. 1972. "The Principles of Paleohydrologeological Reconstruction of Groundwater Formation." Section II, Hydrogeology. In Internat. Geol. Cong., 24th Session, Ed. J. D. Gill, pp. 205-207.

Bradley, W. C. and A. I. Mears. 1980. "Calculations of Flows Needed to Transport Coarse Fraction of Boulder Creek Alluvium at Boulder, Colorado." Geol. Soc. of Am. Bull. Part I, 91(3):1890.

Bray, D. I. 1973. "Regime Relations for Alberta Gravel-Bed Rivers." In Eluvial Processes and Sedimentation. Natl. Research Council of Canada, Ottowa, pp. 440-452.

Bretz, J. H. 1928. "The Channeled Scabland of Eastern Washington." Geographical Review. 18:446-477.

Bretz, J. H. 1929. "Valley Deposits Immediately East of the Channeled Scabland of Washington (Parts 1 and 2)." J. of Geology. 37:393-427.

Bretz, J. H. 1942. "Vadose and Phreatic Features of Limestone Caverns." J. of Geology. 50:675-811.

Bretz, J. H. 1969. "The Lake Missoula Floods and the Channeled Scabland." J. of Geology, $77: 505-543$.

Bretz, J. H., H. T. U. Smith and G. E. Neff. 1956. "Channel Scabland of Washington: New Data and Interpretations." Geol. Soc. of Am. Bull. $67: 957-1049$.

Briggs, G. 1967. "Paleocurrents and Source Areas of Late Paleozoic Sediments of Ouachita Mountains Southeastern Oklahoma." J. of Sedimen. Pet. 37:985.

Briggs, L. I. and G. V. Middleton. 1965. "Hydromechanical Principles of Sedimentary Sedimentary Structure Formation in Primary Structures and Their Hydrodynamic Interpretation." Soc. Econ. Paleon. and Miner., Spec. Publ. No. 12, pp. 5-17.

Broecker, W. S. 1971. "A Kinetic Model for the Chemical Composition of Sea Water." Quarternary Research. 1(2):188-207.

Buckley, J. T. 1969. "Gradients of Past and Present Outlet Glaciers." Geol. Survey of Canada Paper No. 69-29, 13 p.

Bu11, W. B. 1972. "Prehistoric Near-Surface Subsidence Cracks in Western Fresno County, California." Geol. Survey Prof. Paper No. 437-C. 
Burshitar, M. S. and D. A. Nazarov. 1970. "Methods of Constructing Schematic Areal Maps of Paleohydrodynamic Conditions." Soviet Geology. 9:19-33.

Butler, B. E. 1950. "A Theory of Prior Streams as a Casual Factor of Soil Occurrence in the Riverine Plain of Southeastern Australia." Australia J. Agr. Research. 1:231-252.

Butler, B. E. 1961. "Ground Surfaces and the History of the Riverine Plain." Australian J. Science. 24:39-40.

Carr, M. H. 1971. "Formation of Martian Flood Features by Release of Water from Confined Aquifers." J. of Geophys. Research. 84(B6):2995-3007.

Cartwright, D., R. H. Gilkeson, R. A. Griffin, et al. 1981. "Hydrogeologic Considerations in Hazardous-Waste Disposal in Illinois." Illinois State Geol. Survey, N.T.I.S. No. PB81-200024, Springfield, IL.

Casshyyap, S. M. 1968. "Huronian Stratigraphy and Paleocurrent Analysis in Espanol-Willisville Area Sudbury District Ontario Canada." J. of Sedimen. Pet. 38:920.

Chave, K. E. 1960. "Evidence on History of Seawater from Chemistry of Deeper Subsurface Water of Ancient Basins." AAPG Bul1. 44:357-370.

Chiu, Chao-Lin, M. Asce and D. E. Hsiung. 1981. "Seconary Flow, Shear Stress and Sediment Transport." In Proceedings of A.S.C.E. 107(HY6):879-898.

Clague, J. J. 1975. "Sedimentology and Paleohydrology of Late Wisconsinan Outwash, Rocky Mountain Trench, Southeastern British Columbia." Soc. Econ. Paleon. and Miner. Spec. Publ. No. 23, pp. 223-237.

Cody, D. 1971. "Adsorption and the Reliability of Trace Elements as Environment Indicators for Shales." J. of Sedimen. Pet. 41(2):461-471.

Coleman, N. L. 1981. "Velocity Profiles with Suspended Sediment." J. of Hydraul ic Research. 19:211-229.

Cooper, M. A. and J. D. Marshall. 1981. "A Computer Program for the Resolution and Rotation of Paleocurrent Data." Computers and Geos. 7(2)153-165.

Costa, J. E. 1978. "Holocene Stratigraphy in Flood-Frequency Analysis." Geol. Soc. Am. Abstr. Prog. 10:83.

Cotter, E. 1971. "Paleoflow Characteristics of a Late Cretaceous River in Utah from Analysis of Sedimentary Structures in the Ferron." J. of Sedimen. Pet. 41(1):129-138. 
Cox, Allen. 1968. "Polar Wandering, Continental Drift and the Onset of Quaternary Glaciation." Meteorological Monographs. 8(30):112-125.

Craft, F. A. 1973. "The Relationship Between Erosion and Hydrographic Changes in the Upper Murrary Catchment NWS." Linnean Soc. New South Wales Proc. $60: 121-144$.

Crimes, T. P. 1966. "Palaeocurrent Directions in Upper Cambrian of North Wales." Nature. 210:1246.

Curry, R. R. 1966. "Glaciation About 3,000,000 Years Ago in the Sierra Nevada Uplift." Science. 154(3750):770-771.

Cutts, J. A. and K. R. Blasius. 1981. "Origin of Martian Outflow Channels-The Eolian Hypotheses." J. of Geophysical Res. 86(B6):5072-5102.

Dalrymple, T. and M. A. Benson. 1967. "Measurement of Peak Discharge by the Slope-Area Method." In Techniques of Water-Resources Investigations of the United States Geological Survey, Book 3, Chapter A2. U.S. Geol. Survey, Washington, D.C.

Davis, J. 0. 1978. "Late Sehoo Discharge of the Humboldt River; Stratigraphic Archeology at the North Valmy Power Plant, Humbolt County, Nevada." Geol. Soc. Am., Abstr. Prog. 10(7):386.

Davis, M. B. 1964. "Pollen Accumulation Rates: Estimates from Late-Glacial Sediment of Rogers Lake." Science. 145:1293-1295.

Davis, M. B. 1967. "Pollen Accumulation Rates at Rogers Lake, Connecticut, 125 During Late- and Postglacial Time." Rev. Palaeoboi. Palynol. 2:219-230.

Davis, S. N. 1964. "Silica in Streams and Ground Water." Am. Jour. Sci. $262: 870-891$.

Defeyes, K. S., F. J. Lucia and P. K. Wey1. 1965. "Dolomitization of Recent and Plio-Pleistocene Sediments by Marine Evaporite Waters on Bonaire, Netherlands Antilles." Soc. Econ. Paleon. and Miner. Spec. Publ. No. 13.

Degens, E. T. and D. A. Ross. 1972. "Chronology of the Black Sea Over the Last 25,00D Years." Chemical Geology. 10(1):1-16.

Deju, R. A. 1971. Regional Hydrology Fundamentals. Gordon Bard Breach, New York, NY.

Delorme, L. D. 1969. "Ostracodes as Quaternary Paleoecological Indicators." Can. J. Earth Science. 6(6):1471-1476.

Delorme, L. D. 1972. "Groundwater Flow Systems, Past and Present." Section II, Hydrogeology. In Inter. Nat. Geol. Cong., 24th Session, Ed. J. D. Gill, pp. 222-226. 
Deuser, W. S. 1972. "Late Pleistocene and Holocene History of the Black Sea as Indicated by Stable-Isotope Studies." J. of Geophys. Res. 77(6): 1071-1077.

Diester-Haass, L. 1973. "No Current Reversal at 10,000 B.P. in the Strait of Gibraltar." Marine Geology. 15(1):MI-M9.

Ducasse, 0. and J. P. Peypouquet. 1978. "Ostracoda and the Paleographic Evolution and Paleohydrology of the Northeastern Atlantic Continental Margin of Cenozoic Time." Soc. Geol. Fr. Bull. 20(4):441-451.

Dury, G. H. 1964. "Subsurface Exploration and Chronology of Underfit Streams." Geol. Survey Prof. Paper No. 452-B.

Dury, G. H. 1965. "Theoretical Implications of Underfit Streams." Geol. Survey Prof. Paper No. 452-C.

Dury, G. H. 1972. "Some Problems of Basin Loss Rates in the Paleohydrology of Closed Lakes (Abstr.)." Geol. Soc. Am. Abstr. 4(7):494.

Dury, G. H. 1973. "Paleohydrologic Implications of Some Pluvial Lakes in Northwestern New South Wales, Austria." Geol. Soc. of Am. Bull. No. 84.

Ellwood, B. R. and M. T. Ledbetter. 1978. "Paleocurrent Indicators in DeepSea Sediment." Science. 203:1335-1337.

Elson, J. A. 1967. "Geology of Glacial Lake Agassiz." In Life, Land and Water. pp. 37-95, Manitoba Univ. Press., Manitoba, Canada.

Emiliani, C. 1972. "Quaternary Paleotemperatures and the Duration of the High-Temperature Intervals," Science. 178:389-401.

Emiliani, C. 1966. "Paleotemperature Analysis of Caribbean Cores P6304-8 and P6304-9 and a Generalized Temperature Curve for the Past 4." J. of Geology. $74(2): 109-123$.

Emiliani, C. 1961. "Cenozoic Climatic Changes as Indicated by the Stratigraphy and Chronology of Deep-Sea Cores of Globigerina Ooze Fac." Annals New York Academy of Sciences. 95:521-535.

Ethridge, F. G. and S. A. Schumm. 1978. "Reconstructing Paleochannel Morphologic and Flow Characteristics: Methodology, Limitations and Assessment." Can. Soc. Pet. Geol. 5:703-721.

Ettinger, M. and Y. Langozki. 1969. "Hydrodynamics of the Mesozoic Formations in the Northern Negev, Israel." Geol. Survey Isr. Bull. No. 46.

Evans, A. M. 1966. "Paleocurrents in Upper Cambrian of North Wales." Nature. 209: 1230 . 
Feth, J. H., C. E. Roberson and W. L. Palzer. 1964. "Sources of Mineral Constituents in Water from Granitic Rocks in Sierra Nevada, California and Nevada." U.S. Geol. Sur. Water Supply Paper 1535-I.

Feth, J. H. 1981. "Chloride in Natural Continental Water-A Review." Geological Society of America Water-Supply Paper 2176.

Flotgen, F. and G. Milde. 1974. "The Role of Carbonate Rocks in Paleohydrology." Zeit. Fur Ange. Geo. 20(7):313-318.

Foley, M. G. 1977. "Gravel-Lens Formation in Antidune Regime Flow--A Quantitative Hydrodynamic Indicator." J. of Sed. Petrology. 47(2):738-746.

Foley, M. G. 1978. Scour and Fill in Ephemeral Streams. Hydraulics and Water Resources Report. No. KH-R-33, Calif. Inst. Tech., Pasadena, CA.

Foley. M. G. 1980a. "Hydrology." Geotimes. 25:30-31.

Foley, M. G. 1980b. "Bed-Rock Incision by Streams." Geol. Soc. Am. Bull. 91, Part II: 2189-2213.

Foley, M. G. 1981. Computer Simulation of Geologic Systems, PNL-SA-9889A, Pacific Northwest Laboratory, Richland, WA.

Foley, M. G. et al. 1978. "Bed-Load Transport Mechanisms During Flash Floods." In Proceedings of Conference on Flash Floods: Hydrometerological Aspects, pp. 109-116. American Meterological Society, Boston, MA.

Fontes, J. C. and G. Gortolami. 1973. "Subsidence of the Venice Area During the Past 40,000 Years." Nature. 244:339-341.

Frey, D. G. 1974. "Remains of Animals Quaternary Lake Sediments and Their Interpreatation." Engeb. Limnology. 2:1-114.

Fritts, H. C. 1969. "Tree-Ring Analysis: A Tool for Water Resources Research." Trans. Am. Geophys. Union. 50:22-29.

Fritts, H. C. 1970. "Tree-Ring Analysis and Reconstruction of Past Environments." Univ. of British Columbia Faculty of Forestry Bu11. 7:92-98.

Fritts, H. C. 1965. "Tree-Ring Evidence for Climatic Changes in Western North America." Monthly Weather Review. 93:421-433.

Fritts, H. C., T. J. Blasing, B. P. Hayden and J. E. Kutzbach. 1971. "Multivariate Techniques for Specifying Tree-Growth and Climatic Relationships and for Reconstructing Anomalies in Pa'leohydrology." $\mathrm{J}$. of Applied Meterology. 10(5):845-864. 
Fritz, P., E. J. Reardon and F. W. Render. 1977. "Groundwater Age and Stable Isotopes in the Winnipeg Aquifer as Paleoclimatic and Paleohydrologic Indicators." Program Abstr. 2:19 (Waterloo).

Fryxell, R. and E. F. Cook. 1964. "A Field Guide to the Loess Deposits and Channeled Scablands of the Palouse Area, Eastern Washington." Washington State Univ., Pullman, Lab Anthropology, Rept. Invest. 27, 32 p.

Fryzell, R. 1962. "A Radiocarbon Limiting Date for Scabland Flooding." Northwest Science. 36:113-119.

Galehous, J. S. 1967. "Provinance and Paleocurrents of Pasco Robles Formation California." Geol. Soc. Am. Bull. 78:951.

Galehous, J. S. 1968. "Anisotropy of Magnetic Susceptibility as a Paleocurrent Indicator--A Test of Method." Geol. Soc. of Am. Bu11. 79:387.

Galloway, W. E. 1979. "Oakville Formation of Texas Coastal Plain; Depositional Systems, Composition, Structure, Geohydrology and Uranium." Am. Assoc. Pet. Geol. Bull. 63(3):455.

Gardner, T. W. 1977. Paleohydrology, Paleomorphology and Depositional Environments of Some Fluvial Sandstones of Pennsylvanian Age in Eastern Kentucky. Thesis, Univ. Cincinnati. University Microfilms Internat., Ann Arbor, MI.

Gat, J. and A. Issar. 1974. "Desert Isotope Hydrology. Water Resources of the Sinai Desert." Geochim. Cosmochim. Acia. 38:1117-1131.

Garrels, R. M. and C. L. Christ. 1964. Solutions Minerals and Equilibria. Harper and Row, New York.

Geyh, M. A. 1972. "Basic Studies in Hydrology and C-14 and H-3 Measurements." Section II, Hydrogeology. In Inter. Nat. Geol. Cong., 24th Session, Ed., J. D. Gill, pp. 227-236.

Gooding, A. M. 1971. "Postglacial Alluvial History in the Upper White-Water Basin, Southeastern Indiana, and Possible Regional Relationship." Am. J. of Science. 271(4):389-401.

Griffiths, G. A. 1981. "Flow Resistance in Coarse Gravel Bed River." In Proceedings of A.S.C.E. 107 (HY7):899-918.

Grigg, R. W. 1972. "Orientation and Growth Form of Sea Fans." Limnology and Oceanography. $17(2): 185-192$.

Gumerman, G. J., J. A. Hanson, D. Brew, K. Tomoff and C. S. Week. 1975. "The Hydrology of Prehistoric Farming Systems in a Central Arizona Ecotone." Carbondale, IL.

Hack, J. T. 1957. "Studies of Longitudinal Stream Profiles in Virginia and Maryland." U.S. Geol. Survey Prof. Paper No. 294-B, pp. 45-97. 
Hack, J. T. 1960. "Interpretation of Erosional Topography in Humid Temperate Regions." Am. J. Science. 258-A:80-97.

Hahne, R. 1978. "New Methodological Aspects of a Palaeohydrogeological Analysis." Zeit, Fur. Ange. Geo. 24(1):38-42.

Hahne, R. and W. Kluge. 1976. "Reconstruction of Paleohydrodynamic Conditions of Lower Triassic in Central European Basin by Means of Electroanalogy." Zeit, Fur. Ange. Geo. 22(12):574-583.

Hahne, R., S. B. Vagin and A. A. Karcev. 1979. "On the Development and Perspective of Paleohydrology." Zeit. Fur. Ange. Geo. 26(5):243-250.

Hails, J. R. and J. H. Hoyt. 1969. "The Significance and Limitations of Statistical Parameters for Lower Georgia Coastal Plains in Modern Sedimentary Environments." J. of Sedimen. Pet. 39(2):559-580.

Hallsworth, E. G. and G. S. Beckmann. 1969. "Gilgai in the Quaternary." Soil Science. 107(6):409-420.

Hamblin, W. K., P. E. Damon and W. B. Bull. 1981. "Estimates of Vertical Crustal Strain Rates Along the Western Margins of the Colorado Plateau." Geology. 9:293-298.

Hamilton, N. and A. I. Rees. 1970. "The Use of Magnetic Fabric in Paleocurrent Estimation." In Paleogeophysics, Ed., S. K. Runcorn, pp. 445-464. Academic Press, New York, NY.

Hand, B. M. 1969. "Antidunes as Trochoidal Waves." J. of Sedimen. Pet. 39:1302-1309.

Hand, B. M. 1975. "Paleohydraulics of Catastrophic Discharge from Proglacial Lake Syracuse, New York, NY." ABSIB. Prog. 7(1):69-70.

Harding, H. T. 1929. "Possible Water Supply for the Channeled Scab Lands." Science. $69(1781): 188-190$.

Harms, J. C. 1969. "Hydraulic Significance of Some Sand Ripplies." Geol. Soc. Am. Bull. 80:363-396.

Harms, J. C. and R. K. Fahnestock. 1965. "Stratification, Bedforms, and Flow Phenomena (with an example from the Rio Grande)." Soc. Econ. Paleon. and Miner. Spec. Publ. No. 12, pp. 84-114.

Harris, L. D. 1969. "A Lower Paleozoic Paleoaquifer in the Kingsport Formation and Mascot Dolomite of Tennessee." Econ. Geology. 64(3):349.

Haynes, C. V. 1973. "Geochronology and Paleohydrology of the Murray Springs Clovis Site, Arizona (Abstr.)." Geol. Soc. Am. Abstr. 5(7):659. 
Helley, E. J. 1969. "Field Measurement of the Initiation of Large Bed Particle Motion in Blue Creek Near Klamath, California." U.S. Geol. Survey Prof. Paper No. 562-G, 19 p.

Helley, E. J. 1973. "Historic Flood Information for Northern California Streams from Geological and Botanical Evidence." U.S. Geol. Survey Prof. Paper. No. $485 \mathrm{E}$, p. 16 .

Hendy, C. H., M. J. Selby and A. T. Wilson. May 1972. "Deep Lake, Cape Barne-Antarctica." Limnology and Oceanography, 17(3):356-362.

Himida, I. H. 1970. "The Nubian Artesian Basin, Its Regional Hydrogeological Aspects and Palaeohydrogeological Reconstruction." $\mathrm{J}$. of Hydrology. $9(2): 89-116$.

Hoffman, P. 1967. "Algal Stromatolities--Use in Stratigraphic Correlation and Paleocurrent Determination." Science. 257:1043.

Hofmann, H. J. 1966. "Ordovician Paleocurrents Near Cincinnati, Ohio." Nature. $74: 868$.

Holcombe, T. L. and W. S. Moore. 1977. "Paleocurrents in Eastern Caribbean Geologic Evidence and Implications." Marine Geology. 23(1-2):35-36.

Holtz, R. K. and V. R. Baker. 1979. "An Examination of Fluvial Morphological Characteristics of Western Amazon Streams from Appolo-Soyuz Photographs." In Satellite Hydrology. pp. 252-261, Am. Water Resources Assoc., Minneapolis, MN.

Hooper, P. R. and V. E. Camp. 1981. "Deformation of the S.E. Part of the Columbia Plateau." Geology. 9:323-328.

Howard, A. D. 1964. "A Model for Cavern Development Under Artesian Ground Water Flow, with Special Reference to the Black Hills." Natl. Speleol. Soc. Bull. 26:7-16.

Howard, A. and R. Dolan. 1981. "Geomorphology of the Colorado River in the Grand Canyon." J. of Geology. 89(3):269-298.

Hsu, K. J. 1960. "Paleocurrent Structures and Paleogeography of the U1trahelvitic Flysch Basin." Geol. Soc. Am. Bull. 71:577-610.

Huber, N. K. 1981. "Amount and Timing of Late Cenozoic Uplift and Tilt of the Central Sierra Nevada, California--Evidence from the Upper San Joaquin River Basin." Geol. Survey Prof. Paper No. 1197, 28 p.

Hyndam, D. W. 1981. "Controls on Source and Depth of Emplacement of Granite Magma." Geology. 9:244-249. 
Inden, R. F. 1972. "Paleogeography, Paleohydrology, and Diagenes is of Middle Trinity (lower Cretaceous) Carbonate Sequence, Texas (Abstr.)." Am. Assoc. Pet. Geol. Bull. 56(3):630.

Issar, A. 1969. "The Paleohydrology of Southern Israel and Its Influence on the Flushings of the Kurnub and Arad Groups Lower Cretace." J. of Hydrology. 44(3-4):289-303.

Issar, A., A. Bein and A. Michaeli. 1972. "On the Ancient Water of the Upper Nubian Sandstone Aquifer in Central Sinai and Southern Israel." J. of Hydrology. 17:353-374.

Jacob, A. F. 1973. "Elongate Concretions as Paleochannel Indicators, Tongue River Formation (Paleocene), North Dakota." Geol. Soc. Am. Bull. $84(6): 2127-2132$.

Jones, J. R. 1970. "Hydrologic Evaluation of Gemini Photographs of Fringes of the Sahara, Africa." N.A.S.A. 68:13.

Jordan, G. F. 1962. "Large Submarine Sand Waves." Science. 136:839-848.

Kafri, U. and A. Arad. August 1976. "Paleohydrology and Migration of the Ground-Water Divide in Regions of Tectonic Instability in Israel." Geol. Soc. of Am. Bull. 87(12):1723-1732.

Kalinin, G. P., R. K. Klige and V. A. Shleynikov. 1976. Main Problems of Paleohydrology. 1zd. Nauka, U.S.S.R.

Karcz, I. 1965. "Triassic Palaeocurrent Pattern in Har Arif Area (southern Israel)." ISB J. Earth. 14:45.

Karcz, I. 1966. "Secondary Currents and Configuration of a Natural Stream Bed." J. of Geophys. Research. 71:3109.

Karcz, I. 1967. "Ripple Controlled Desiccation Patterns from Wadi Shiqma Southern Israel." J. of Sedimen. Pet. 37:1244.

Karcz, I. 1968. "Paleocurrents in Triassic Sandstones of Arayif En-Naqa, Sinai." Isb J. Earth. 17:9.

Kartsev, A. A., S. Borisovich, et a1. 1969. Outline of Principles, Significance of Paleohydrologic Data for Study of Ground Waters, Tectonic Activity and Magnetism, 0il and Gas Exploration. Izd. Nedra, Moscow.

King, G. C. P. and C. Vita-Finzi. 1981. "Active Folding in the Algerian Earthquake of 0ctober 10, 1980." Nature. 292:22-26.

Kirkland, J. T. and R. E. Funk. 1978. "Archeological Predictions from the Distribution of Flood Plain Sediments Along the Upper Susquehanna River Valley, New York." Geol. Soc. of Am., Abstr. Prog. 10(7):435. 
Kister, L. R. and W. F. Hardt. 1961. "Correlation of Ground-Water Quality with Different Sediment Types, Lower Santa Cruz Basin, Arizona." Ariz. Geol. Soc. Digest. 4:79-85.

Klein, G. de V. 1967. "Paleocurrent Analysis in Relation to Modern Marine Sediment Dispersal Patterns." Am. Assoc. of Pet. Geol. Bull. 51:366-326.

Klitzsch, E. and D. W. Baird. 1969. "Stratigraphy and Paleohydrology of the Germa (Jarma) Area Southwest Libya." Pet. Explor. Soc. Libya Annu. Field Conf. No. 11, pp. 67-80.

Kluge, W. and R. Hahne. 1978. "Some Essential Prerequisites of Reconstructing Hydrodynamic Processes in Space and Time (Paleohydrodynamics)." Zeit. Fur Ange. Geo. $24(9): 388-394$.

Kluge, W. and G. Milde. 1975. "Theoretical Bases for a Reconstruction of Pal eohydrodynamic Conditions." Zeitschrift Fur Angewandie, Geologie. $21(7): 315-322$.

Komar, P. D. 1978. "Comparisons of the Hydraulics of Water Flows in Martian Outflow Channels with Flows of Similar Scale on Earth." Icabus. 37:156-181.

Koster, E. H. 1977. "Pal eohydraulic Interpreatation of Coarse-Grained Alluvium Using Transverse Ribs." Abstr. Programs. 9(3):287-288.

Kotoda, K. 1975. The Water Balance of Lake Biwa-Ko and Paleohydrology. Kyoto Univ., Japan.

Kuetsch, G. 1962. "Untersuchungen an Grundwassern Der Ostsahara." Geol. Bundshau. 52:587-160.

Laming, D. J. C. 1966. "Imbrication, Palaeocurrents and Other Sedimentary Features in the Lower New Red Sandstone, Devonshire, England." J. of Sedimen. Pet. 36:940-959.

Lamoreaux, P. E., H. E. Legrand, V. T. Stringfield and J. S. Tolson. 1975. "Hydrology of Limestone Terraines." Geol. Survey of Alabama Bull. No. 94, Part E, Geol. Geol. Survey of Alabama, University, AL.

Land, L. S., M. R. Salem and D. W. Morrow. 1975. "Paleohydrology of Ancient Dolomites; Geochemical Evidence." Am. Assoc. Pet. Geol. Bull. 59(9): 1602-1625.

Langford-Smith, T. 1959. "Disposition on the Riverine Plain of Southeastern Australia." Australian J. Sci. 22:73-74.

Lanez, R. L. 1965. "A Comparison of the Chemical Composition of Rainwater and Ground Water in Wester North Carolina." U.S. Geol. Survey Prof. Paper 525-C. 
Larman, A. 1970. "Chemical Equilibria and Evolution of Chloride Brines." Mineralog. Soc. Amer. Spec. Paper. 3:291-306.

Larson, T. E. 1949. "Geologic Correlations and Hydrologic Interpretation of Water Analyses." Illinois State Water Survey Division Circular 27.

Latouche, C. and N. Maillet. 1978. "Mineralogy of the Deposits of DSDP/IPOD Sites 398 (Leg 47B) and 403,404, 405, 406 (Leg 48). Paleoclimatic and Paleohydrological Implications." Bull. Soc. Geol. Er. Ser. 7 . (Paris) $20(4): 411-427$.

Lee, G. F. and W. Wilson. 1969. "Use of Chemical Composition of Freshwater Clamshells as Indicators of Paleohydrologic Conditions." Ecology. $50(6): 990-997$.

LeGrand, H. E. and V. T. Stringfield. 1966. "Development of Permeability and Storage in the Tertiary Limestones of the Southeastern States, U.S.A." Internat. Assoc. Sci. Hydrology Bul1. 11(4):61-73.

Leopold, L. B., M. G. Wolman and J. P. Miller. 1964. Fluvial Processes in Geomorphology. W. H. Freeman, San Francisco, CA.

Leopold, L. B. and M. G. Wolman. 1960. "River Meanders." Geol. Soc. Am. Bull. $71: 769-794$.

Leopold, L. B. and T. Maddock, Jr. 1953. "The Hydraulic Geometry of Stream Channels and Some Physiographic Implications." U.S. Geol. Survey Prof. Paper. No. 252, p. 57 .

Lindgren, w. 1911. "The Tertiary Gravels of the Sierra Nevada of California." U.S. Geol. Survey Prof. Paper. No. 73, p. 226.

Lombard, R. E., M. B. Miles, L. M. Nelson, D. L. Kresch and P. J. Carpenter. 1981. "Channel Conditions in the Lower Toutle and Cowlitz Rivers Resulting from the Mudflows of May 18, 1980." Geol. Survey Circular No. 850-C., 15 p.

Mabey, D. R. 1971. "Geophysical Data Relating to a Possible Pleistocene Overflow of Lake Bonneville at Gem Valley, S.E. Idaho." Geol. Survey Prof. Paper No. 750-B.

Mabey, 0. R. and F. C. Armstrong. 1962. "Gravity and Magnetic Anomalies in Gem Valley, Caribou County, Idaho." U.S. Geol. Survey Prof. Paper. No. 450-D, pp. D73-D75.

Makkaveyev, N. I. and A. M. Kalinin. 1968. "Experimental Paleohydrologic Investigations." Soviet Hydrology Selected Papers, No. 3.

Makkaveyev, N. I. and A. M. Kalinin. 1968. "An Experiment in Paleohydrologic Research." Ser. Geog. 4:15-22, Akad., U.S.S.R. 
Makki, M. S. 1979. "Dams Around the Holy City of Medina, and the Pressure on Its Water Supply." J. of Arid Environ. 2:363-367.

Malde, H. E. 1968. "The Catastrophic Late Pleistocene Bonneville Flood in the Snake River Plain, Idaho." U.S. Geol. Survey Prof. Paper. No. 596, p. 52 .

Mansfield, G. R. 1938. "Flood Deposits of the Ohio River, January-February 1937." U.S. Geol. Survey Water Supply Paper, No. 838, pp. 693-736.

Martini, 1. P. 1971. "A Test of Validity of Quartz Grain Orientation as a Paleocurrent and Paleoenvironmental Indicator." J. of Sedimen. Pet. $41(1): 60-68$.

Mathr, J. D. 1968. A Literature Survey of the Use of Radioisotopes in GroundWater Studies. National Environment Research Council.

Matthes, F. E. 1930. "Geologic History of the Yosemite Valley." U.S. Geol. Survey Prof. Paper No. 160, 137 p.

Maucci, W. 1972. "The Surficial Paleohydrology of Karstic Terranes--with Discussion." In La Protezione E La Valorizzazione Dei Eenomeni Cargici; Atti Del 1.0, pp. 97-107.

Mazor, E. and F. Mero. 1969. "The Origin of the Tiberias-Noit Mineral Water Association in the Tiberias-Dead Sea Rift Valley, Israel." J. of Hydrology. $7: 318-333$.

Mckee, E. D. 1938. "Original Structures in Colorado River Flood Deposits of Grand Canyon." J. of Sedimen. Pet. 8:77-83.

McSaveney, E. C. 1976. Terraces of the Hocking River Basin, Ohio: Particle Morphology and Paleohydrology. Thesis, Ohio State Univ. Zerox Univ. Microfilms, Ann Arbor, Michigan.

McTigue, D. F. 1981. "Mixture Theory for Suspended Sediment Transport," in Proceedings of A.S.C.E. $107($ Hy6): $659-673$.

Mehringer, P. J. Jr. 1967. "Pollen Analysis and the Alluvial Chronology: The Kiva." J. of the Arizona Archaeol. and Hisi. Soc. 32:96-100.

Meisler, H. and A. E. Becker. 1967. "Hydrogeologic Significance of CalciumMagnesium Ratios in Ground Water from Carbonate Rocks in Lancaster Quadrangle Southeastern Pennsylvania." In Geological Survey Research 1967-U.S. Geol. Survey Prof. Paper 575-C.

Melton, M. A. 1965. "The Geomorphic and Paleoclimatic Significance of Alluvial Deposits in Southern Arizona." J. of Geology. 73:1-37.

Meyerson, A. L. 1972. "Pollen and Paleosalinity Analyses from a Holocene Tidal Marsh Sequence, Cape May County, New Jersey." Marine Geology. $12(5): 335-357$. 
Mial1, A. D. 1976. "Paleocurrent and Paleohydrologic Analysis of Some Vertical Profiles Through a Cretaceous Braided Stream Deposit, Banks Island, CA." Sedimentology. 23:459-483.

Mial1, A. D. 2974. "Paleocurrent Analysis of Alluvial Sediments Discussion of Directional Variance and Vector Magnitude." J. of Sedimen. Pet. 44(4): 1174-1185.

Mickelson, D. M. and H. W. Borns, Jr. 1972. "Chronology of a Kettle-Hole Peat Bog, Cherryfield, Maine." Geol. Soc. Am. Bull. 83(3):827-832.

Mifflin, M. D. and M. Wheat. 1977. "Pluvial Lakes of Nevada and Estimated Full Fluvial Climates." Nevada Univ. Water Resources Center. Available from N.T.I.S. as PB-267-721, Springfield, VA.

Milde, G. 1969. "Contributions to Working Technique of Paleohydrology." Zeii. Eur Ange. Geo. 15:368.

Milde, G., U. Hagendorf and U. Tetzlaff. 1969. "Research Methods in Paleohydrogeology; Arbeitsmethodische Beitrage Zur Palaohydrogeologie." Zeit. Fur Ange. Geo. 15(7):368-373.

Mishra, S. K. 1967. "Kinetics and Mechanism of Oxidation of Hypophosphite by $\mathrm{Ce}(4)$ in Sulfuric Acid Solution." J. of Inorg. Nuc. 29:1643.

Mishra, S. K. 1967. "A Preliminary Investigation of Paleocurrents in Central and South-Western Parts of Vindhyan Basin." Current Science. 36:579.

Moody, U. L. 1977. "Correlation of Flood Deposits Containing St. Helens Set S Ashes and the Stratigraphic Position of St. Helens Set J. and Glacier Peak Ashes." Geol. Soc. Am. Abstr. Prog. 9(7):1098-1099.

Mooh, W. G. 1972. "Application of Natural Isotopes in Grounwater Hydrology." Geol. Mynboun. 51.

Moore, J. D., G. F. Moravec and P. E. LaMoreaux. 1975. "Hydrology of Limestone Terranes, Quanititative Studies." Geol. Survey of Alabama Bull. No. 94-F, $93 \mathrm{p}$.

Morgan, J. J. 1967. "Chemical Equilibria and Kinetic Properties of Manganese in Natural Waters." In Principles and Applications of Water Chemistry, eds. S. J. Fuast and J. V. Hunter, pp. 561-624. John Wiley and Son, New York.

Morgan, K. H. 1972. "The Relationship Between Rainfall, Geomorphic Development and the Occurrence of Groundwater in Precambrian Rocks of Western Australia." Section II, Hydrogeology. In Internat. Geol. Cong., 24th Session, Ed., J. D. Gi11, pp. 242-252. 
Moss, J. H. 1978. "Unexpected Geomorphic Effects of the Hurricane Agnes Storm and Flood, Conestoga Drainage Basin, Southeastern Penn." J. of Geology. $86: 1-11$.

Mullineaux, D. R. 1978. "Age of the Last Major Scabland Flood of Eastern Washington." U.S. Geol. Survey Prof. Paper No. 110D, p. 78.

Narayan, J. 1971. "Sedimentary Structures in the Lower Greensand of the Weald, England, and Bas-Boulonnais, France," Sedimentary Geology. 6:73-109.

Narayan, J. 1971. "Graphical Method for Calculating Vector Mean Azimuth and Magnitude for Paleocurrent Analysis." J. of Geology. 79:478.

Nathan, S. and J. S. Fruchter. 1974. "Geochemical and Paleomagnetic Stratigraphy of the Picture Gorge and Yakima Basalts in Central Oregon." Geol. Soc. Am. But1. 85:63-76.

Neuman, J. and R. M. Sigrist. 1978. "Harvest Dates in Ancient Mesopotamia as Possible Indicators of Climatic Variations." Climatic Change. 1:239-252.

Nevin, C. 1946. "Competency of Moving Water to Transport Debris." Geo1. Soc. Am. Bu11. 57:651-674.

Obediyentova, G. V. 1974. "Rivers of the Past: Creators of 0i1." N.A.S.A. TT F-15,974.

Osby, D. R. and L. D. McGinnis. 1977. "Paleohydrology of Taylor Valley, Antarctica, Inferred from Salinity of Pore Ice in Drill Core." Trans. Am. Geophys. Union. 58(6):385.

Osmond, J. K. and J. B. Cowart. 1976. "Uranium Isotopes in Groundwater as a Clue to Palaeohydrology and Palaeoclimatology." Int. Geol. Cong.

25:478. (Sydney).

Padgett, G. V. and R. Ehrlich. 1976. "Paleohydrologic Analys is of a Late Carboniferous Fluvial System, Southern Morocco." Geol. Soc. Amm. Bull. $87(8): 1101-1104$.

Park, C. F. Jr. and R. A. MacDiarmid. 1975. Ore Deposits. 3rd Edition. W. H. Freeman, San Francisco, California.

Parker, J. W. 1969. "Water of Cretaceous Aquifers, East Texas Basin." Chemical Geology. 4:111-133.

Patton, P. C. 1977. Geomorphic Criteria for Estimating the Magnitude and Frequency of Flooding in Central Texas. Univ. Texas, Austin, TX.

Patton, P. C. 1979. "Slack-Water Deposits: A Geomorphic Technique for the Interpretation of Fluvial Paleohydrology." In Adjustments of the Fluvial System, Ed., D. D. Rhodes, pp. 225-253. KendalT-Hunt Pub. Co., Dubuque, ID. 
Patton, P. C. and V. R. Baker. 1976. "Morphometry and Floods in Small Drainage Basins Subject to Diverse Hydrogeomorphic Controls." Water Resources Research. 12:941-952.

Patton, P. C. and D. S. Dibble. 1978. "Archeological and Geomorphic Evidence for the Paleohydrologic Record of the Pecos River in West Texas." Geol. Soc. Am. Abstr. Prog. 10(7):469.

Pearson, F. J. Jr., and D. E. White. 1967. "Carbon 14 Ages and Flow Rates of Water in Carrizo Sand, Atuscosa County, Texas." Water Resources Research. $3: 251-261$.

Pearson, F. J. Jr. and B. B. Hanshaw. 1970. "Sources of Dissolved Carbonate Species in Groundwater and Their Effects on Carbon-14 Dating." In Isotope Hydrology. IAEA, Vienna.

Pels, S. 1964. "The Present and Ancestral Murray River System." Australian Geog. Studies. 2:111-119.

Pels, S. 1966. "Late Quaternary Chronology of the Riverine Plain of Southeastern Australia." Geol. Soc. Australia J. 13-27-40.

Pe1s. S. 1960. "The Geology of the Murrumbidgee Irrigation Areas and Surrounding Districts." Water Conservation and Irrigation Commission, Groundwater and Drainage Series, Bull. No. 5, 43 p.

Pels, S. 1964. "Quaternary Sedimentation by Prior Streams on the Riverine Plain, Southwest of Griffith, New South Wales." Royal Soc. New South Wales, J. and Proc. 97:107-115.

Pelletier, B. R. 1965. "Paleocurrents in the Triassic of Northeastern British Columbia." Soc. Econ. Paleon. and Miner. Spec. Publ. No. 12, pp. 233-245.

Petta, T. J. 1976. Diagenesis and Paleohydrology of a Budist Reef Complex (Cretaceous), Bandera County, Texas. Thesis, Louisiana State Univ., Baton Rouge, LA.

Picard, M. D. and L. R. High. 1971. "Differentiation of Lacustrine and Fluvial Sandstone by Analys is of Paleocurrent Patterns." Am. Assoc. Pet. Geol. 55:540.

Plummer, P. S. and P. I. Leppard. 1979. "Analytical Technique for Uni, Bi, and Trimordial Paleocurrent Data." Computers and Geog. 5(52):157-172.

Pohn, H. A. 1981. "Joint Spacing as a Method of Locating Faults." Geology. $9: 258-261$.

Polish Academy of Sciences. 1969. "Geographia Polonida." Geographia Polonida. $17: 428$. 
Potter, P. E. and F. Pettijohn. 1963. Paleocurrent and Basin Analysis. Springer-Verlag, Berlin.

Pouchan, P. and C. Moussie. 1973. "Lacustrine Paleohydrology in the Afars and Issas Territory and in Afar (Abstr.)." Reun. Annu. Sci. Terre, Programme Resumes. 344 p.

Pribyl, J. 2973. "Paleohydrology of the Caves in the Moravsky Kras (Moravian Karst)." Studia Geographica No. 28, Brno, 64 p.

Priddy, R. R. 2955. "Fresh Water Strata of Mississippi Revealed by Electrical Analog Stuides." Miss. State Geol. Survey Bu11. No. 83, 71 p.

Raju, D. S. N. 1965. "Pa leocurrents in Miocene Rajahmundry Formation Andhra Pradesh India." J. of Sedimen. Pet. 35:758.

Ramaswamy, C. 1968. "Monsoon Over the Indus Valley During the Harappan Period." Nature. 217:628-629.

Razumiskhin, N. V. 1975. "Outline of Water Balance During the MesozoicCenozoic Time and Some Problems of Paleohydrology." Vypusk. 12(2):76-85, Leningrad, U.S.S.R.

Reardon, E. J. and P. Fritz. 1978. "Computer Modelling of Groundwater ${ }^{13} \mathrm{C}$ and ${ }^{14} \mathrm{C}$, Isotope Compositions." Jour. Hydokal. 36:301-224.

Richmond, G. M. and P. L. Weis. 1965. "Maximum Extent of Late Pleistocene Cordilleran Glaciation in Northeastern Washington and Northern Idaho." U.S. Geol. Survey Prof. Paper. No. 525-C, pp. C128-C132.

Riggs, H. C. 1976. "A Simplified Slope-Area Method for Estimating Flood Discharges in Natural Channels." J. Research U.S. Geol. Survey. $4(3): 285-291$.

Riley, J. 1975. "The Channel Shape-Grain Size Relation in Eastern Australia and Some Paleohydrologic Implications." Sedimentary Geology. 14(4):253-258.

Ronov, A. B. 1968. "Probable Changes in the Composition of Sea Water During the Course of Geologic Time." Sedimentology. 10:25-43.

Rust, B. R. 1972. "Pebble Orientation in Fluvial Sediments." J. of Sedimen. Pet. 42(2):384-388.

Rust, B. R. and V. A. Gostin. 1982. "Fossil Transverse Ribs in Holocene Alluvial Fan Deposits, Depot Creek, South Australia." J. of Sedimen. Pet. 51:441-444.

Said, R. 1975. "Some Observations on the Geomorphological Evolution of the South-Western Desert of Egypt and Its Relation to the Origin of Ground Water." Egypt Geol. Survey, Ann. 5:61-70. 
Sakhibgareyeu, R. S. and V. A. Moskvich. 1975. "Effect of Hydrodynamic Conditions, Existing During Deposition of Organic Material, on Reservoir Properties of the Zadonsk Beds of the Pripyat Trough." Doklady Akad. Nauk SSSR. 219(1-6): 174-176.

Salmenkova, N. A., V. G. Tyminskity and A. N. Sultankhodzhayev. 1967. "Evaluation of the Possibilities of Exploration by Hydrogeologic Methods." Uzbek. Geol. Zh. 1:82-85.

Sanger, J. E. and E. Gorham. 1972. "Stratigraphy of Fossil Pigments as a Guide to the Postglacial History Kirchner Marsh, Minnesota." Limnol. Oceanography. 17:840-854.

Saunders, J. W. 1974. "Paleohydrology of Crump Spring Cave, Central Kentucky Karst." In Proc. Conf. Karst Geol. Hydrol. No. 4, pp. 129-135.

Savage, J. C., M. Lisowski and W. H. Priscott. 1981. "Geodetic Strain Measurements in Washington." $\mathrm{J}$. of Geophysical Res. 86(B6):4929-4940.

Schmidt, V. A. 1976. "The Paleohydrology for Laurel Caverns, Pennsylvania." Natl. Speoleol. Soc. Annu. Conv., Morgantown, WV., Annu. Conv. Guideb., Natl. Speoleol, Soc., pp. 32-35.

Schubel, J. R. and O. B. Zabawa. 1972. "Reaches of the Chester, Miles, and Choptank Estuaries, Maryland." Chesapeake Bay Inst. Spec. Report No. 24, 12 p.

Schubel, J. R. and C. F. Zabawa. 1972. "A Pleistocene Susquehanna River Channel Connects the Lower Reaches of the Chester, Miles, and Choptank Estuaries." Chesapeake Bay Institute Special Report No. 24, 12 p.

Schumm, S. A. 1960. "The Shape of Alluvial Channels in Relation to Sediment Type." U.S. Geol. Survey Prof. Paper No. 352-B.

Schumm, S. A. 1967. "Paleohydrology Application of Modern Hydrologic Data to Problems of the Ancient Past." In Proc. Int. Hydrology Symposium. pp. 185-193, Fort Collins, C0.

Schumm, S. A. 1972. "Fluvial Paleochannels, in Recognition of Ancient Sedimentary Environments." Soc. Econ. Paleon. and Miner. Spec. Publ. No. 16, pp. 98-108.

Schumm, S. A. 1969. "River Metamorphosis." In Proceedings of A.S.C.E. $6352(H Y 1): 255-273$.

Schumm, S. A. 1963. "The Disparity Between Present Rates of Denudation and Orogeny." U.S. Geol. Survey Prof. Paper. No. 454-H, p. 13.

Schumm, S. A. 1969. "Speculations Concerning Paleo-Hydrologic Controls of Terrestrial Sedimentation." Geo1. Soc. of Am. Bul1. 79(11):1573-1588. 
Schumm, S. A. 1965. "Quaternary Pal eohydrology." In The Quaternary of the United States. Princeton Univ. Press, Princeton, N.J.

Schumm, S. A. 1963. "A Tentative Classification of Alluvial River Channels." U.S. Geol. Survey Circular No. 477, 10 p.

Schumm, S. A. 1977. The Fluvial System. John Wiley and Sons, Inc., New York, NY.

Schumm, S. A. 1968. "River Adjustments to Altered Hydrologic RegimenMurrumbridge River and Paleochannels, Australia." Geol. Survey Prof. Paper No. $598,65 \mathrm{p}$.

Selley, R. C. 2968. "A Classification of Paleocurrent Models." J. of Geology. $76(1): 99-110$.

Selley, R. C. 1967. "Paleocurrents and Sediment Transport in Nearshore Sediments of the Sirte Basin, Libya." J. of Geology. 75:215-223.

Selley, R. C. 1968. "Facies Profile and Other New Methods of Graphic Data Presentation-Application in a Quantitative Study of Libyan Tertiary Shorline Deposits." J. of Sedimen. Pet. 38:363.

Shaw, J. and R. Kellerhals. 1977. "Paleohydraulic Interpretation of AntiDune Bedforms with Applications to Anti-Dunes in Gravel." Miss. State Geol. Survey Bull. 47(1):257-266.

Shepherd, R. G. and S. A. Schumm. 1974. "Experimental Study of River Incision." Geol. Soc. Am. Bull. 85:257-268.

Sheman, J. 0. 1976. Computer Applications for Step-Backwater and Floodway Analyses. U.S. Geol. Survey Open File Report 76-499, Washington, D. C.

Shishkina, 0. V. 1974. "Possible Use of Data on Chlorine Distribution in Interstitial Waters for Paleohydrochemical Reconstructions." Oceanology-U.S.S.R. 14(6):867-872.

Sigafoos, R. S. 1964. "Botanical Evidence of Floods and Flood-Plain Oeposition." U.S. Geol. Survey Prof. Paper No. 485-A.

Simons, D. B., E. V. Richardson and C. F. Nordin, Jr. 1965. "Forms Generated by Flow in Alluvial Channels." Soc. Econ. Paleon. and Miner. Spec. Publ. No. 12 , pp. 34-52.

Simpson, R. W. and A. Cox. 1977. "Paleomagnetic Evidence for Tectonic Rotation of the Oregon Coast Range." Geology. 5:585-589.

Skarzyns, K. 1965. "Paleohydrological Research in Territory of Ancient Poland." B Pol Geol. 13:237-241. 
Skipper, K. 1971. "Antidune Cross-Stratification in a Turbidite Sequence, Cloridome Formation, Gaspe, Quebec." Sedimentology. 17:51-68.

Smith, G. I. 1978. "A 3,000,000 Year Record of Continental Evaporite Deposition in Searles Lake, California." Presented at Int. Cong. Sedimen., July 9-14, 1978, Jerusalem.

Smith, G. I. 1977. "Late Pleistocene Pluvial Chronology in the Southwest." Geol. Soc. of Am. Abstr. with Prog. 9(7):1180.

Smith, L. P. and C. W. Stockton. 1981. "Reconstructed Stream Flow for the Salt and Verde Rivers from Tree-Ring Data." Water Resources Bulletin. $17(6): 939-947$.

Smith, R. S. U. 1978. "Late Pleistocene Paleohydrology of Pluvial Lake Panamint, California." Geol. Soc. of Am., Abstr. Prog. 10(3):148.

Soderman, L. G. and Y. D. Kim. 1970. "Effect of Groundwater Levels on Stress History of the St. Clair Clay Till Deposit." Canadian Geochemical J. $7: 173$.

Stanley, D. J. and A. H. Douma. 1954. Methodology and Paleogeographic Interpretation of Flysch Formations: A Summary of Studies in the Maritime ATps. pp. 34-64. Elsevier Pub. Co., Amsterdam, Netherlands.

Stannard, M. E. 1962. "Prior-Stream Deposition." Australian J. Science. $24: 324-325$.

Stark, D. M. 1976. "Paleolimnology of Elk Lake, Itasca State Park, Northwestern Minnesota." Arch. Hydrobio. Supp. No. 50, pp. $208-274$.

Stefan, H. G., M. Asce and A. C. Demetracopouious. 1981. "Cells-in-Series Simulation of Riverine Transport." In Proceedings of A.S.C.E. 107(HY6): 675-696.

Stewart, J. E. and G. L. Bodhaine. 1961. "Floods in the Skagit River Basin, Washington." U.S. Geol. Survey Water Supply Paper No. 1527, 66 p.

Stoffers, P. and G. Muller. 1972. "Clay Mineralogy of Black Sea Sediments." J. of Sedimentology. 18:113-121.

Stringfield, V. T., P. E. LaMoreaux and H. E. LeGrand. 1974. "Karst and Paleohydrology of Carbonate Rock Terranes in Semiarid and Arid Regions with a Comparison to Humid Karst." Alabama Geol. Survey Bull. 105:106.

Strum, E. 1971. "High Resolution Paleocurrent Analysis by Moving Vector Averages." Geol. Soc. Am. Bull. 82:481. 
Sultankhodzhayev, A. N., V. G. Tyminskiy and N. A. Surgandva. 1969.

"Paleohydrogeological Analysis Principles of Artesian Basins." Geol. J. of Uzbek. 1:49-53.

Swain, A. M. 1973. "A History of Fire and Vegetation in Northeastern Minnesota as Recorded in Lake Sediments." Quaternary Research. 3:383-396.

Swain, F. M. 1965. "Geochemistry of Some Quaternary Lake Sediments of North America." In The Quaternary of the United States, Princeton Univ. Press, New Jersey.

Swenson, F. A. 1968. "New Theory of Recharge to the Artesian Basin of the Dakotas." Geol. Soc. of Am. Bull. 79:163-182.

Swenson, H. A. 1953. "Geochemical Relationships of Water in the Powder River Basin, Wyoming and Montana." Am. Geophys. Union Trans. 34:443-448.

Tanner, W. F. 1967. "Ripple Mark Indices and Their Uses," Sedimentology. 9:89-104.

Thomas, O. M. and M. A. Benson. 1970. "Generalization of Streamflow Characteristics from Drainage Basin Characteristics," U.S. Geol. Survey Water Supply Paper, No. 1955,55 p.

Thrailkill, J. 1968. "Chemical and Hydrologic Factors in the Excavation of Limestone Caves." Geol. Soc. Am. Bull. 79(1):19-45.

Tinkler, K. J. 1971. "Active Valley Meanders in South-Central Texas and Their Wider Implications." Geol. Soc. Am. Bull. 82(7):1783-1799.

Trevena, A. S. 1975. Depositional Models and the Shinarump Member and Member and the Sonsela Sandstone Bed of the Chinle Formation, Northeastern Arizona and Northwestern New Mexico. Thesis, Univ. Arizona, Phoenix, Az.

U.S. Army. 1973. HEC-2: Water Surface Profile, Users Manual. U.S. Army Corps of Engineers, Hydrologic Engineering Center, Oavis, CA.

U.S. Geological Survey. 1978. "Remote Sensing and Advanced Techniques: Applications to Hydrologic Studies." U.S. Geol. Survey Prof. Paper No. 1100 , pp. 312-314.

Valyoslko, M. G. and N. K. Vlasona. 1965. "On the Process of Formation of Calcium Chloride Brines." Geokhimiya.

Vessel, R. K. 1977. Morphology, Hydrology, and Sedimentology of Rio GuacalateVolcanic Highlands - Guatemala. Unpub. M. A. Thesis, Univ. Missourí, Columbia, $144 \mathrm{p}$.

Vessel, R. K. et al. 1977. "Sedimentology and Hydrology of Flood Flows on the Active Volcano Fuego, Guatemala." Geol. Soc. Am. Abstr. with Prog. 9:1210-1211. 
Visher, G. S. 1965. "Fluvial Processes as Interpreted from Ancient and Recent Fluvial Deposits--Primary Sedimentary Structures and Their Interpretation." Soc. Econ. Paleon. and Miner. Spec. Pubt. No. 12, pp. 116-132.

Vladimirov, L. A. 1962. Average Annual Flow of Georgian Rivers. Izd. an Gruz., U.S.S.R.

VonButtlar, H. and I. Wandt. 1958. "Ground-Water Studies in New Mexico Using Tritium as a Tracer." Am. Geophys. Union Trans. 31:660-668.

Vouve, J. 1975. Study of Hydrogeology and Karst Paleohydrology: Volume I, General Principles and Analytic Methods Applied to Karsi Hydrology. Thesis, Univ. Bordeaux. Bordeaux, France.

Wagner, W. P. 1971. "Glacial Geology of the Champlain Valley." Completion Report to the Office of Resources Research, the Dept. of Interior, PB197882, N.T.I.S., Springfield, VA.

Way, D. S. 1978. Terrain Analysis. Dowden, Hutchinson, and Ross Inc., Stroudsburg, PA.

Weigle, J. M. 1972. "Exploration and Mapping of Salisbury Paleochannel, Wicomico County, Maryland." Maryland Geol. Survey, Bul1. No. 31, Part 2, pp. 63-93.

Wernicke, B. June 1981. "Low-Angle Normal Faults in the Basin and Range Province Nappe Tectonics in an Extending Orogen." Nature. 291:645-648.

Weyl, P. K. 1958. "The Solution Kinetics of Calcite." Journal of Geology. $66: 163-176$.

White, D. E. 1957. "Magmatic, Connate, and Metamorphic Waters." Geol. Soc. of Am. Bull. 68:1659-1682.

White, W. B. and G. H. Deike. 1964. "Preliminary Results on the Paleohydrology of Mammoth Cave and the Flint Ridge Cave System (Abstr.)." Geol. Soc. of Am. Spec. Paper No. 76, p. 320.

Wigley, T. M. L. 1975. "Carbon 14 Dating of Groundwater from Closed and Open Systems." Water Resources Research. 11:324-328.

Williams, G. E. 1967. "Moinian Paleaoccurrent Directions at Faraid Head Sutherland." Geol. Magazine. 104:298.

William, G. P. 1969. "Erosional and Depositional Aspects of Hurricane Camille in Virginia." U.S. Geol. Survey Prof. Paper, No. 804, 80 p.

Williams, M. A. J., J. D. Clark, D. A. Adamson and R. Gillespie. 1975. "Recent Quaternary Research in Central Sudan." Assoc. Senegal. Etud. Quat. Afr. Bul1. 46:75-86. 
Williams, M. A. J. and H. Faure (eds) 1980. The Sahara and the Nile: Quaternary Environments and Prehistoric Occupation in Northern Africa. A. A. Balkema, Netherlands.

Winograd, I. J. and G. C. Doty. 1980. "Paleohydrology of the Southern Great Basin, with Special Reference to Water Table Fluctuations Beneath the Nevada Test Site During the Late Pleistocene." U.S. Geol. Survey Open File Report No. 80-569, 91 p.

Winograd, I. and F. N. Robertson. 1982. "Deep Oxygenated Groundwater: Anomaly or Common Occurrence?" Science. 216:1227-1230.

Yadon, D. A. 1961. "On the Origin and Accumulation of Salts in Groundwater and Soils of Israel." Department of Geology, Hebrew University, Jerusalem. Publication 255.

Zak, I. 1968. "Significance of Some Sedimentary Structures from Mount Sedom." ISB J. Earth. $17: 1$.

Zot1, J. 1961. "Die Hydrographie De Nordostalpinen Karstes." Steirische Beitr Hydrogeol. 2:54-183. 
(1996) 


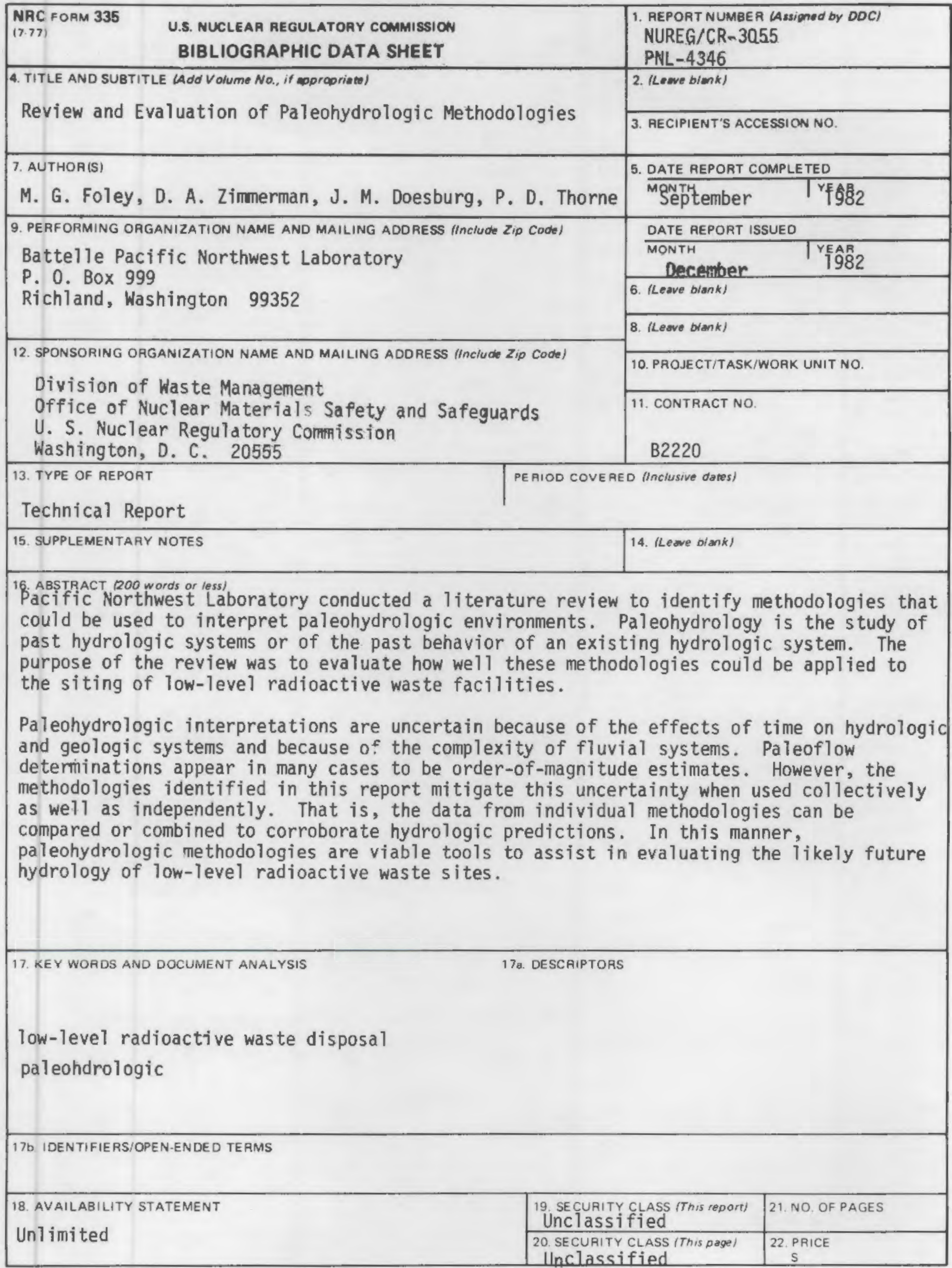


